Federal Reserve Bank of Dallas

Globalization and Monetary Policy Institute

Working Paper No. 211

https://www.dallasfed.org/ /media/documents/institute/wpapers/2014/0211.pdf

\title{
Hot Money and Quantitative Easing: The Spillover Effects of U.S. Monetary Policy on the Chinese Economy*
}

\author{
Steven Wei Ho \\ Columbia University \\ Ji Zhang \\ Tsinghua University \\ Hao Zhou \\ Tsinghua University \\ November 2014 \\ Revised: February 2017
}

\begin{abstract}
We develop a factor-augmented vector autoregression (FA-VAR) model to estimate the effects that unexpected changes in U.S. monetary policy and economic policy uncertainty have on the Chinese housing, equity, and loan markets. We find the decline in the U.S. policy rate since the Great Recession has led to a significant increase in Chinese housing investment. One possible reason for this effect is the substantial increase in the inflow of "hot money" into China. The responses of Chinese variables to U.S. shocks at the zero lower bound are different from those responses in normal times.
\end{abstract}

JEL codes: F3, C3, E4

\footnotetext{
* Steven Wei Ho, Department of Economics, Columbia University, 420 West $118^{\text {th }}$ Street, Office $1105 B$, Mail Code 3308, New York, NY 10027. 212- 854-5146. sh3513@columbia.edu. Ji Zhang, PBC School of Finance, Tsinghua University, 43 Chengfu Road, Beijing, 100083, China. zhangji@pbcsf.tsinghua.edu.cn. Hao Zhou, PBC School of Finance, Tsinghua University, 43 Chengfu Road, Beijing, 100083, China. zhouh@pbcsf.tsinghua.edu.cn. We thank Serena Ng and Jushan Bai for helpful comments on the methodology. We are grateful to two anonymous referees and editor Pok-Sang Lam, whose comments have greatly improved the paper. We also thank Mark Wynne, Donald Kohn, Canlin Li (discussant), Hongyi Chen, Jianfeng Yu, and Jian Wang for helpful comments and feedbacks. We are also grateful for the participants at CICF 2015 for kind suggestions. The views in this paper are those of the authors and do not necessarily reflect the views of the Federal Reserve Bank of Dallas or the Federal Reserve System.
} 


\section{Introduction}

Since the Great Recession, the federal funds rate, the primary tool of U.S. monetary policy, has hit the zero lower bound (ZLB) for extended periods, and researchers have been keenly interested in investigating how this unconventional U.S. monetary policy and its tapering affect emerging markets, particularly the Chinese market. Although China is the world's largest emerging economy, questions have arisen about the existence and magnitude of the spillover effects, because the Chinese capital account is not fully open and Chinese exchange rates are not flexible. Nevertheless, earlier studies by Miniane and Rogers (2007) found that capital controls cannot insulate developing countries from U.S. monetary shocks. Is it true, then, that U.S. monetary policy has had little spillover effect on the Chinese economy?

We investigate this question in this paper, and we also study the manner in which the central bank of China, the People's Bank of China (PBoC), reacts to U.S. monetary policy shocks. We use the shadow rate measure as constructed by Wu and Xia (2016) as an extension of the effective federal funds rate during the times when the ZLB is binding, and this measure is designed to capture the U.S. monetary policy stance when unconventional monetary policies are implemented. Moreover, since the outbreak of the most recent financial crisis in the United States, economists have wondered whether uncertainty regarding U.S. economic policy has detrimental effects on the U.S. economy. Thus, we will also study whether any spillover effects on the Chinese economy occur due to U.S. economic policy uncertainty, as measured by the EPU index recently proposed by Baker et al. (2015). 
Our estimation results suggest that the presence of significant crosscountry spillover effects. We find that an expansionary U.S. monetary policy shock boosts Chinese real estate investment during the ZLB period. However, the market interest rate, trade balance, and exchange rate do not change significantly in response to the same shock. This result suggests that U.S. monetary policy shocks do not affect the Chinese economy through the market interest rate or trade channels. This finding is consistent with the earlier finding of Canova (2005) that trade channels played an insignificant role in the effect of U.S. monetary shocks on Latin American countries during the 1980-2002 period. Our results suggest that so-called hot money may play an important role in the transmission mechanism, which resonates with the finding of Prasad and Wei (2007) that "hot money", rather than trade surplus, is the most important component of reserve accumulation in China. We also find that the responses of the Chinese economy to U.S. monetary policy shocks and policy uncertainty shocks exhibit different dynamics in periods before and after the federal funds target rate hit the ZLB in the United States. This result suggests the existence of structural changes both in the Chinese economy and in the transmission mechanism of U.S. monetary policy.

In terms of methodology, we use a broad set of Chinese economic indicators and run a factor-augmented vector autoregression (FA-VAR) model to estimate the effects that shocks in both the U.S. policy rate and U.S. policy uncertainty have on the Chinese economy. Fernald et al. (2014) and He et al. (2013) used a similar methodology to study the Chinese economy, although those studies focus on the effects of Chinese monetary policy shocks without 
addressing the impact of U.S. monetary policy and policy uncertainty shocks on China's economy.

Employing the FA-VAR approach benefits this study in four ways. First, and most importantly, we are able to include a large number of data series - 161 Chinese data series in our FA-VAR model - to make full use of information without being constrained by concerns about preserving the degree of freedom, as is the case with a standard VAR approach. Moreover, measuring policy shocks correctly is known to be difficult, and so a second advantage of the FA-VAR approach is to help us address the potential endogeneity issues that arise from the notion that the Federal Reserve may adjust monetary policy in response to economic conditions in China. ${ }^{\dagger}$ The third benefit is that this approach also minimizes our dependence on arbitrary choices regarding which variables to include in a VAR (Evans and Marshall, 2009). Given that China is an important consideration in U.S. monetary policy decisions, it is not immediately clear which Chinese variables one should include in the VAR model. ${ }^{\ddagger}$ This problem is addressed by using the FA-VAR model, in which we are able to extract factors from a large number of Chinese variables. The fourth advantage is that the FA-VAR methodology allows us to study the impacts of U.S. monetary policy on the general Chinese

$\dagger$ The recent minutes of the Federal Open Market Committee (FOMC) meetings explicitly cite the slowing growth in China as part of the staff review of the economic situation (Madigan, 2016a). In addition, Federal Reserve Chair Janet Yellen has singled out China as a central risk factor in current global growth prospects (Fleming, 2016). Endogeneity concerns are also supported by historical precedents, such as when the Fed lowered short-term U.S. interest rates in light of the Russian default and Asian financial crises in the late 1990s (Neely, 2004).

${ }^{\ddagger}$ For example, the January 2016 FOMC minutes mentioned "a modest pickup in growth of Chinese manufacturing output," and the April 2016 FOMC minutes mentioned "China's management of its exchange rate," whereas the December 2015 FOMC minutes referred to "favorable economic indicators in China" without specifying the identities of the indicators. 
economy. U.S. monetary policies may have either direct or indirect impacts on any of the 161 Chinese variables, and we can plot the impulse responses of these Chinese variables due to unpredicted innovation in U.S. monetary policy, after controlling for a rich information set.

Related Literature Maćkowiak (2007) uses the structural VAR approach to study the effects of an external shock on eight emerging economies (Hong Kong, Korea, Malaysia, the Philippines, Singapore, Thailand, Chile and Mexico) which are assumed to be small open economies that have no influence on U.S interest rates, although U.S. interest rates may substantially affect them. However, this assumption does not apply to China. China is a large trading partner with the United States, and according to a World Bank (2014), China will soon become the largest economy in the world based on purchasing power parity; thus, the state of the Chinese economy is certainly on the mind of central bankers around the world, which may pose endogeneity challenges for this methodology. Maćkowiak (2007) finds U.S. monetary shocks affect the real output and price levels in emerging economies even more strongly than the real output and price levels in the United States. Furthermore, a U.S. monetary shock can quickly affect short-term interest rates and exchange rates in emerging markets. In our FA-VAR approach, we find the impact of U.S. monetary shocks on Chinese industrial production to be rarely statistically significant, nor do they affect the RMB/USD exchange rate due to the managed floating of the $\mathrm{PBoC}$, although these shocks can substantially Chinese interest rates before the zero lower bound.

Chang, Liu and Spiegel (2015) use a DSGE framework to investigate the 
optimal monetary policy of China, which currently implements capital control and nominal exchange rate targets as well as sterilization of foreign capital by swapping exporters' foreign-currency revenues with domestic-currency bonds. Under the current set of policies, which mandates both capital control and an exchange rate peg, the authors have found this combination prevents effective monetary policy adjustments that would maintain stable macroeconomic conditions as well as shield China from the impact of fluctuations in foreign capital. We indeed observe, from Figures 3 and 4 in our findings, that a significant inflow of hot money and an increase in Chinese real estate investments occur as a result of quantitative easing policies in the United States, and the current monetary policies of China are not effective in preventing booms and swings in housing investments as a result of fluctuations of foreign capital inflows. Chang et al. (2015) also argue that liberalizing either the capital account or the exchange rate would be welfare increasing.

Mumtaz and Surico (2009) applied the FA-VAR approach in order to study the international transmission of structural shocks on the U.K.'s economy. Moreover, Aastveit et al. (2014) have built a structural FA-VAR model to analyze the contribution of developed and emerging countries to oil market variables.

Dedola et al. (2013) have studied the global implications of unconventional monetary policies. Their key finding is that, in general, a lack of cooperation between countries will result in suboptimal credit policies. In our results, we find that the $\mathrm{PBoC}$ takes contractionary credit measures by raising required reserve ratio in response to expansionary monetary policy shocks in the United States. These measures are plausibly aimed at restricting the credit available 
to the Chinese economy when hot money flows into China. Failing to respond in this manner might lead to higher than optimal credit availability in the Chinese economy.

The remainder of this paper is structured as follows. Section 2 illustrates the model and data we use. Section 3 contains the results and analysis. Section 4 concludes.

\section{FA-VAR Model and Data}

\section{1. $\quad$ Model}

We use the FA-VAR model developed by Bernanke et al. (2005) to investigate the effects of both U.S. monetary policy and U.S. policy uncertainty on the Chinese economy. Let $X_{t}(N \times 1$ vector $)$ denote a large number of observed macroeconomic time series that contain rich information on economic conditions. We also have observed variables $Y_{t}(M \times 1$ vector $)$, and we aim to investigate how the shock to $Y_{t}$ affects $X_{t}$. In this paper, we study the impact of two particular variables: the U.S. monetary policy rate and policy uncertainty.

However, using all the series in $X_{t}$ in a structural VAR analysis is challenging because, although hundreds of series exist, the number of observations in each series is small. Fortunately, many studies have confirmed that a few factors can explain a large fraction of the variance in many macroeconomic series. Therefore, instead of directly using every macroeconomic series, the informational series are summarized using a small number of unobservable fac- 
tors $F_{t}(K \times 1$ vector $)$. We also include three U.S. macro variables-industrial production, unemployment, and CPI represented by $Z_{t}(J \times 1$ vector $)$, in the VAR system - to accommodate the expected changes in U.S. monetary policy. This is because U.S. monetary policy mainly depends on price and output gap, following a Taylor-type policy rule. The dynamics of $Z_{t}, F_{t}$, and $Y_{t}$ are assumed to follow this transition equation:

$$
\left(\begin{array}{c}
Z_{t} \\
F_{t} \\
Y_{t}
\end{array}\right)=\Phi(L)\left(\begin{array}{c}
Z_{t-1} \\
F_{t-1} \\
Y_{t-1}
\end{array}\right)+\epsilon_{t}
$$

where $\Phi(L)$ is a polynomial of the lag operator and $\epsilon_{t}$ is the error term with zero mean and covariance matrix $\Sigma$. We assume the error term can be represented as linear combinations of structural shocks: $\epsilon_{t}=P U_{t}$. The structural shocks $\left(U_{t}\right)$ we consider here include U.S. monetary policy shocks, $u_{t}^{U S m p}$; U.S. policy uncertainty shocks, $u_{t}^{U S p u}$; and other structural shocks that are not our focus and will not be identified in this paper.

However, equation (1) cannot be estimated directly, because the factors $F_{t}$ are unobservable. We further assume that our macro series, $X_{t}$, is related to the latent factors $F_{t}$, and observed U.S. policy measures $Y_{t}$, by the observation equation:

$$
X_{t}=\Lambda^{f} F_{t}+\Lambda^{y} Y_{t}+e_{t}
$$

Because the factors $F_{t}$ are unobserved, they are substituted by $\widehat{F}_{t}$, estimated from 161 Chinese macro series and U.S. policy measures in two steps. First, we extract principal components $\widehat{C}_{t}$ from $X_{t}$. All principal components 
are normalized to have unit variances. Second, to ensure the identification of the VAR system used later, we remove any direct dependence of the factors $\widehat{C}_{t}$ on $Y_{t}$ and identify the policy shocks recursively. To do so, we separate all the Chinese variables into two categories: fast-moving variables and slow-moving variables. A variable is classified as slow moving if it is largely predetermined at present, for instance, industrial production, unemployment, and so on. A variable is classified as fast moving if it is highly sensitive to contemporaneous economic news or shocks, such as asset prices. The classification of variables between these two categories is provided in Appendix C.1. The slow-moving

factors $\widehat{F}_{t}^{s}$ are estimated as principal components of all slow-moving variables, and not affected by contemporaneous shocks to the policy measures by assumption. Then, as shown in regression equation (3), we regress the common principal components of all macro series on the policy measures and the slow-moving components to obtain the estimators of coefficients $b_{F^{s}}$ and $b_{Y}$ :

$$
\widehat{C}_{t}=b_{F} \widehat{F}_{t}^{s}+b_{Y} Y_{t}+e_{t}
$$

The latent factors $\widehat{F}_{t}$, which we use in the following VAR analysis, are then constructed from $\widehat{C}_{t}-\widehat{b}_{Y} Y_{t}$.

\subsection{VAR Specification and Shock Identification}

Our VAR system contains eight variables, five of which are U.S. variables - including unemployment rate, industrial production index, CPI, monetary policy rate, and policy uncertainty index - and three of which are the 
Chinese factors extracted from 161 Chinese macro series. We include the U.S. unemployment rate, U.S. industrial production, and U.S. CPI to tease out some of the anticipated components of the U.S. monetary policy shock attributed to domestic economic conditions in the United States. The FA-VAR methodology is particularly suitable for us because we merely want to know how U.S. monetary policy affects the Chinese economy in general. Since all 161 series contain information on the Chinese macro economy, we prefer to use all of the information instead of only selecting a few series we judge as important.

We use monthly data from January 2000 to February 2014. Due to the short sample, we use a VAR system with one lag according to the AIC, BIC and HQ statistics.

We order the variables in the VAR system from the most exogenous to the least exogenous, thus: U.S. unemployment rate, U.S. industrial production index, U.S. CPI, three Chinese latent factors $\widehat{F}_{t}$, U.S. monetary policy shock, and U.S. policy uncertainty shock. The error term $\epsilon(t)$ is a linear combination of structural shocks, $U(t)$, that correspond to the shocks to the variable in the same ordering as just described. The matrix $P$ is the Cholesky decomposition of the variance-covariance matrix. So the identification of structural shocks is achieved by putting short-term constraints on the responses of variables. More precisely, we identify the two shocks that we are interested in, namely, U.S. monetary policy shock and U.S. policy uncertainty shock, by assuming that U.S. unemployment, industrial production, and CPI, along with the three Chinese factors do not have a contemporaneous response to U.S. monetary policy shock, and that the first seven variables in the VAR system do not 
have a contemporaneous response to U.S. policy uncertainty shock.

In the absence of the factors, the ordering of variables is similar to what Bekaert et al. (2013) and Colombo (2013) did, that is, they placed the policy uncertainty last, and with the effective federal funds rate representing U.S. monetary policy ordered after U.S. CPI but before policy uncertainty. Indeed, this ordering captures the assumption that policy uncertainty responds instantly to monetary policy shocks, but not vice versa, whereas the business cycle variable is relatively slow moving. The position of the Chinese factors in the ordering allows the possibility that the Chinese economy can have contemporaneous impacts on U.S. monetary policy and policy uncertainty. This assumption is reasonable in light of Federal Reserve Chair Janet Yellen's frequent mention of the Chinese economy in conjunction with discussions of the monetary policies of the Federal Reserve as reported in Fleming (2016). In addition, the recent minutes of the FOMC have mentioned the slowdown in China's industrial sector as part of the Federal Reserve staff review of the economic situation (Madigan, 2016b). Moreover, the construction of factors also ensures that the two shocks we are interested in, namely U.S. monetary policy shock and policy uncertainty shock, do not affect Chinese factors contemporaneously, because the "fast-moving" part of the factors has already been removed according to equation (3). In addition, the assumption that U.S. monetary policy shocks and policy uncertainty shocks do not induce any contemporaneous responses from U.S. unemployment, U.S. industrial production, and U.S. CPI is standard in the literature. The ordering of Chinese factors after the U.S. unemployment rate, U.S. industrial production index and U.S. CPI reflects the assumption that we allow, though do not require, the 
possibility that the factors could be influenced by contemporaneous changes in output, price level and unemployment rate in the United States, given that the United States is China's largest trading partner, and a significant part of the Chinese economy is geared toward exports to the United States. In summary, we impose the contemporaneous restrictions as follows:

$$
\epsilon_{t}=P \times U_{t}=\left[\begin{array}{cccccccc}
\times & 0 & 0 & 0 & 0 & 0 & 0 & 0 \\
\times & \times & 0 & 0 & 0 & 0 & 0 & 0 \\
\times & \times & \times & 0 & 0 & 0 & 0 & 0 \\
\times & \times & \times & \times & 0 & 0 & 0 & 0 \\
\times & \times & \times & \times & \times & 0 & 0 & 0 \\
\times & \times & \times & \times & \times & \times & 0 & 0 \\
\times & \times & \times & \times & \times & \times & \times & 0 \\
\times & \times & \times & \times & \times & \times & \times & \times
\end{array}\right] \times\left[\begin{array}{c}
u_{t}^{U \text { Sunemp }} \\
u_{t}^{U S i p} \\
u_{t}^{U S c p i} \\
u_{t}^{C N f 1} \\
u_{t}^{C N f 2} \\
u_{t}^{C N f 3} \\
u_{t}^{U S m p} \\
u_{t}^{U S p u}
\end{array}\right]
$$

The VAR system is estimated through OLS estimation. We can obtain the coefficients of impulse responses of all variables in the VAR system to the U.S. monetary policy shock and policy uncertainty shock. With these coefficients and the transition equation (1), we can back out the impulse responses of all Chinese macro variables in $X_{t}$ to U.S. policy shocks. The $90 \%$ confidence intervals on the impulse responses shown in Appendix A.2 and Appendix A.3 are obtained from a bootstrap procedure based on Kilian (1998). 


\subsection{Data and Estimation}

We include 161 monthly macroeconomic series in China, and the complete table of variables included is found in Appendix C.1. The sample period runs from January 2000 to February 2014. We choose to begin with the year 2000 based on data availability. All series except for policy variables are adjusted for the Chinese New Year effect as described by Fernald et al. (2014) and then adjusted for seasonality by using the U.S. Census Bureau X-13 program. We address missing values through the EM algorithm introduced by Stock and Watson (2002).

The estimation method follows Bernanke et al. (2005) as shown in section 2. We first extract the first three principal components of the observed macroeconomic series over our sample period and then separate out the part in the principal components that is orthogonal to $Y_{t}$ as factors $F_{t}$. Next, we estimate the transition equation, equation (1), and the observation equation, equation (2), with OLS. The impulse response functions and variance decomposition of each macroeconomic series can be obtained by combining the estimation results of these two equations.

We separate the full sample period into two subsamples. The first period runs from January 2000 to December 2008, and the second runs from January 2009 to February 2014. The second period corresponds to the period during which the effective federal funds rate is very close to zero and the Federal Reserve has implemented several unconventional monetary policies. We get our main results from the estimation using the second subsample, and use the estimation with the first subsample as a contrast. 
To incorporate unconventional monetary policy during the ZLB period, the U.S. policy-rate measure we use in the second subsample is the shadow rate proposed by Wu and Xia (2016), as constructed in Appendix D. This series is obtained from the authors and is plotted in Figure 1.

The measure of U.S. policy uncertainty we use is the prominent news-based measure proposed by Baker et al. (2015), as shown in Figure 2 .

\section{Results}

We choose representative variables of the Chinese economy to investigate their dynamics in response to U.S. monetary policy shocks and U.S. policy uncertainty shocks in section 3.1. Note that we display responses of only 11 Chinese variables out of the 161 that, in principle, could be investigated. We set the U.S. monetary policy shock to be an unanticipated 25 basis points decrease in the U.S. policy rate. The size of this U.S. monetary policy shock is around $10 \%$ of the standard deviation of the policy rate. The U.S. policy rate is represented by the effective federal funds rate during normal times, and by the $\mathrm{Wu}$-Xia shadow rate at the ZLB. We set the U.S. policy uncertainty shock to be an unanticipated increase in the uncertainty measure, and this shock size is $10 \%$ of the standard deviation of the uncertainty measure. The top, bottom, and middle lines correspond to the $90 \%$ bootstrap confidence intervals and the bootstrap median, respectively. The unit of the $\mathrm{x}$-axis is time measured in months, and the unit of the y-axis is standard deviation, that is, the figures report impulse responses in units of standard deviation.

For each of the two shocks we are interested in, we present results from two 
subsamples $^{\dagger \dagger}$ : first from January 2009 to February 2014, which corresponds to the ZLB period, and then from January 2000 to December 2008, which corresponds to the pre-ZLB period. For each subsample, we first show what would happen to Chinese variables if the economy were hit by an expansionary U.S. monetary policy shock, and then show what would happen to Chinese variables when there is a positive U.S. policy uncertainty shock.

One thing to note here is that the impulse responses of the Chinese variables are not the ones directly derived from the VAR system, because no specific Chinese variables are in the VAR. We first obtain the impulse responses of Chinese factors from the VAR system, and then back out the responses of each Chinese variable by combining the standard impulse responses of the factor variables in the VAR system and the observation equation (2). The $R^{2}$, represents the goodness of fit, for equation (2), of the common components, including the Chinese factors and U.S. monetary policy and policy uncertainty measures. The average $R^{2}$ for each Chinese variables is $45 \%$ at the ZLB period. We note that the factors explain a sizable fraction of these Chinese variables, especially for some of the most prominent macroeconomic indicators: industrial sales (78\%), SHIBOR (95\%), and real estate investment (92\%).

Besides the impulse responses, we also compare the relative contributions of U.S. monetary policy shock and policy uncertainty shock to the forecast errors of representative Chinese variables at the ZLB in section 3.3. This part helps us evaluate the relative importance of the two types of U.S. shocks to Chinese economy.

\footnotetext{
${ }^{\dagger \dagger}$ Since we focus on the ZLB period, from which we draw our main conclusions, the subsamples are ordered here and presented in the following part in reverse chronologically.
} 


\subsection{Impulse Responses at the Zero Lower Bound}

Figure 3 to Figure 6 report the impulse responses to U.S. monetary policy shocks and policy uncertainty shocks at the ZLB.

\subsubsection{Impulse Responses to U.S. Monetary Policy Shock at the Zero Lower Bound}

Figure 3 demonstrates the effects of an expansionary U.S. monetary policy shock on the Chinese economy when the ZLB of the effective federal funds rate is binding. The U.S. monetary policy-rate shock that we have identified does raise the U.S. industrial production when an expansionary U.S. monetary policy shock is in place. The required reserve ratio, which is an important policy instrument of the $\mathrm{PBoC}$, has a persistent increase in response to an expansionary U.S. monetary policy shock. Although the response of the required reserve ratio is not statistically significant in the long run, its magnitude is very large, with its bootstrap median reaching above 0.5 standard deviation in the long run. The SHIBOR rate has no significant response to U.S. monetary policy shocks when at a $90 \%$ confidence interval, which implies that U.S. monetary policy shocks do not affect the Chinese economy through the market interest rate. The Shanghai Stock Exchange index (SSE Composite) increases significantly in the first several months in response to U.S. monetary policy shocks.

The same figure also displays the responses of the real estate market. Investment in real estate began to rise significantly from the beginning of the period, and this rise is somewhat persistent. Unlike the stock market, 
the Chinese real estate market becomes more attractive when interest rates in the United States are low. The sticky demand for housing and the local government's revenue incentives provide security for the boom of the Chinese real estate market when the United States enters into quantitative easing. For foreign investors, instead of investing in the United States with a low rate of return, investing in the Chinese real estate market might be a more attractive option. For Chinese investors, on the other hand, investing in real estate might be an effective hedge against concerns about imported inflation.

Figure 4 shows that the RMB exchange rate with respect to the U.S. dollar and foreign direct investment (FDI) does not respond significantly to U.S. monetary policy shocks, nor is there any significant impact on the Chinese trade balance or Chinese exports to the United States. However, the same figure shows a significant increase in foreign hot money flowing into China in response to expansionary U.S. monetary policy shocks. Although the significant increase in hot money only lasts for several months, it is consistent with the notion that hot money flows across borders quickly. "Hot money" is approximated by subtracting the trade surplus (or deficit) and net flow of foreign direct investment from the change in foreign reserves, as in Martin and Morrison (2008). Thus, we can infer from the IRFs that the channel through which U.S. monetary policy spills over into China is mainly the hot money channel rather than the trade or exchange rate channels. The fact that we observe increases in the SSE Composite Index and in real estate investment is consistent with the notion that the flow of hot money into these two markets can create booms. The hot money story is also consistent with the increase in the required reserve ratio in Figure 3: a substantial 
inflow of foreign currency largely increases foreign reserves, and hence money base, because of the adoption of a compulsory settlement system. In order to sterilize the increase in money supply, the $\mathrm{PBoC}$ has to raise the required reserve ratio, in order to lower the money multiplier and limit money creation.

Based on the figures discussed above, we can formulate the hypothesis that U.S. monetary policy has spillover effects on China's real economy, but that these effects are not transmitted to China through the market interest rate, trade, or exchange rate channels.

\subsubsection{Impulse Responses to U.S. Policy Uncertainty Shock at the Zero Lower Bound}

Figure 5 shows that, at the ZLB, a positive U.S. policy uncertainty shock does increase the required reserve ratio in China. The changes in the required reserve ratio can be viewed as a policy response of the PBoC to U.S. policy uncertainty. Because we are using the FA-VAR approach, after controlling for a rich set of Chinese and U.S. variables, we find that the $\mathrm{PBoC}$ may raise the required reserve ratio to caution against potential domestic over-investments when U.S. policy uncertainty increases at the zero lower bound.

Figure 6 shows that, at the ZLB, a positive U.S. policy uncertainty shock has no significant effect on Chinese importing and exporting, trade balance, FDI, or hot money.

\subsection{Impulse Responses before the Zero Lower Bound}

Figures 7 to 10 illustrate the impulse responses of variables to U.S. monetary policy shocks and U.S. policy uncertainty shocks before the federal funds rate 
hit the ZLB.

\subsubsection{Impulse Responses to U.S. Monetary Policy Shock before the Zero Lower Bound}

The responses of certain Chinese variables before the ZLB are different from those at the ZLB. For example, in Figure 7 we see that, with an expansionary U.S. monetary policy shock, a significant increase in real estate investment still occurs, although the economic significance is larger when comparing the magnitude when at the ZLB. Notably, in Figure 8 we see that a significant inflow of hot money still occurs in response to a lowering of the effective federal funds rate, but the magnitude of the inflow is smaller than when at the ZLB. The timing is also different in that, rather than having an immediate response as in the ZLB case, now the inflow of hot money occurs several months after the shock in the United States.

\subsubsection{Impulse Responses to U.S. Policy Uncertainty Shock before the Zero Lower Bound}

The reaction to an increase in U.S. policy uncertainty differs significantly between these two periods. A significant increase occurs in the required reserve ratio at the ZLB, but not for the pre-ZLB, in response to increased U.S. policy uncertainty. This result can be interpreted as an indication that, during the period when the ZLB is binding in the United States, the PBoC may be concerned that increases in U.S. policy uncertainty could lead to an inflow of cheap credit from overseas, resulting an overheated Chinese economy. Thus the $\mathrm{PBoC}$ may be attempting to curb over-investment in 
China by increasing the required reserve ratio; however, the $\mathrm{PBoC}$ is not that concerned about increases in U.S. policy uncertainty before the ZLB became binding in the United States. In addition, if we look at the responses of the U.S. variables, we find that increases in U.S. policy uncertainty would decrease U.S. industrial production before the ZLB period, but not when the ZLB is binding.

The differing responses of the Chinese variables can be explained from two perspectives. The first is that the Chinese economy has undergone substantial changes in recent years. Both the interest rate and the exchange rate systems changed significantly during the 2000s. Beginning in 2005, a managed floating exchange rate was implemented, based on market supply and demand with a basket of currencies. The bond market has also grown and the liberalization of the interest rate was slowly and gradually taking place. All these changes affect the responses of macroeconomic variables to U.S. monetary policy shocks. However, we acknowledge that the difference in the results of the pre-ZLB versus the ZLB periods could be due to the fact that the Wu-Xia shadow rate and the effective federal funds rate are different objects, because one cannot know for sure which has changed, the propagation mechanism or the monetary policy variable.

\subsection{Variance Decomposition}

Variance decomposition represents the fraction of the forecasting error of a variable, at a given horizon, that is attributable to a particular shock. Following the same logic of obtaining the impulse response of each Chinese 
variable, we first get the variance decomposition of factors in the VAR system and then use the observation equation (2) to back out the variance decomposition of each Chinese variable. Following Bernanke et al. (2005), we define the fraction of $k$ th-month ahead variance of $X_{i, t+k}-\hat{X}_{i, t+k \mid t}$ due to the U.S. monetary policy shock as

$$
V D\left(u_{t}^{U S m p}, k\right)=\frac{\operatorname{var}\left(X_{i, t+k}-\hat{X}_{i, t+k \mid t} \mid u_{t}^{U S m p}\right)}{\operatorname{var}\left(X_{i, t+k}-\hat{X}_{i, t+k}\right)}
$$

where $X_{i, t}$ represents the $i$ th variable in $X_{t}$, and $\hat{X}_{i, t}$ is the estimated value of $X_{i, t}$. Similarly, we can define $V D\left(u_{t}^{U S p u}, k\right)$ as the fraction of the $k$-month forecasting error of a variable that is attributable to U.S. policy uncertainty shock as

$$
V D\left(u_{t}^{U S p u}, k\right)=\frac{\operatorname{var}\left(X_{t+k}-\hat{X}_{t+k \mid t} \mid u_{t}^{U S p u}\right)}{\operatorname{var}\left(X_{t+k}-\hat{X}_{t+k}\right)}
$$

A standard result of the VAR literature is that U.S. monetary policy shock accounts for a small fraction of the forecast errors for U.S. real economic activity. Intuitively, U.S. monetary policy shocks should not play a very important role in accounting for the forecast errors of Chinese macro variables. Therefore, instead of looking at the absolute value of the variance decomposition, we are more interested in the relative importance of U.S. monetary policy shocks and policy uncertainty shocks to the Chinese economy. We use the ratio between the fraction of the forecast errors caused by U.S. monetary policy shocks and those forecast errors caused by U.S. policy uncertainty 
shocks to represent the relative importance:

$$
V D_{\text {ratio }}(k)=\frac{V D\left(u_{t}^{U S m p}, k\right)}{V D\left(u_{t}^{U S p u}, k\right)}
$$

The second to fourth columns of Table 1 present $V D_{\text {ratio }}(k)$ where $k=$ the 3rd, 6th, and 12th months during the ZLB period. We find that, at the ZLB period, U.S. policy uncertainty shock played a less important role than did U.S. monetary policy shock. For example, the amount of the 3-month forecasting error of real estate investment explained by the U.S. monetary policy shock is 52 times the amount explained by U.S. policy uncertainty shock. An explanation of the relative importance, between U.S. monetary policy shock and policy uncertainty shock, would involve the U.S. monetary policy features at the ZLB. First, although the traditional U.S. monetary policy measure, effective federal funds rate, does not move much at the ZLB, the shadow rate still undergoes significant changes and investors are paying more attention on the Fed's medium- to long-term monetary policy stance rather than transitory variations within the trend, and therefore the first moment or level effect dominates the second moment effect. Second, since the federal funds rate hit the ZLB, the Fed has used forward guidance to communicate with the public about monetary policy and reduce market uncertainty.

\subsection{Further Discussions}

In terms of the role of the PBoC, the March 18th, 1995 Law of the People's Republic of China on the People's Bank of China, states that the PBoC shall 
"under the leadership of the State Council, formulate and implement monetary policies, guard against and eliminate financial risks, and maintain financial stability" and also "maintain the stability of the value of the currency and thereby promote economic growth." According to the trilemma argument, the PBoC has to abandon capital mobility in order to maintain the stated objective of currency stability and monetary policy autonomy that are aligned with the needs of Chinese economic growth. However, as Miniane and Rogers (2007) have indicated, capital controls have little or no effect, because they can be avoided or evaded at little cost. Hence, even if the PBoC wishes to take the option of exercising monetary autonomy with a managed exchange rate, but with capital controls because of the policy trilemma, those capital controls cannot be perfectly enforced. Prasad and Wei (2007) and Prasad and Ye (2012) have extensively documented the time line of the capital control policies in place in China. In fact, China's capital controls are noted to be "leaky" by Glick and Hutchison (2013). Klein and Shambaugh (2013) found that narrowly targeted capital controls do not endow the monetary authority with policy autonomy, and "gates" only work if they function more like "walls"; that is, limited capital controls would not be effective, but pervasive capital controls would be effective in limiting asset price booms and swings. We therefore agree with the literature's implications that, even by having a closely monitored exchange rate and imperfectly enforced capital control regime, the $\mathrm{PBoC}$ does not in fact have full autonomy in monetary policy. Therefore the Chinese economy is more susceptible to swings in capital flow and asset prices than under a fully floating exchange rate regime. 


\section{Conclusion}

Contrary to the notion that U.S. monetary policy shocks have no significant impact on China, we find that such shocks do have significant spillover effects on the Chinese economy. Since the Great Recession, a decline in U.S. policy rates has resulted in a significant increase in Chinese housing investments, possibly as a result of the substantial inflow of hot money into China. The responses of variables to U.S. shocks during the period at the zero lower bound differ from those in normal times, which suggests structural changes in both the Chinese economy and the U.S. monetary policy transmission mechanism. In addition, increases in U.S. policy uncertainty have negative effects on Chinese real estate investment during normal times, but not at the zero lower bound. 


\section{References}

Aastveit, Knut Are, Bjørnland, Hilde C and Thorsrud, Leif Anders. (2014). 'What drives oil prices? Emerging versus developed economies', Journal of Applied Econometrics .

Baker, Scott R, Bloom, Nicholas and Davis, Steven J. (2015), 'Measuring economic policy uncertainty', Technical report, National Bureau of Economic Research.

Bekaert, Geert, Hoerova, Marie and Duca, Marco Lo. (2013). 'Risk, uncertainty and monetary policy', Journal of Monetary Economics 60(7), 771-788.

Bernanke, Ben S, Boivin, Jean and Eliasz, Piotr. (2005). 'Measuring the effects of monetary policy: A factor-augmented vector autoregressive (FAVAR) approach', Quarterly Journal of Economics 120(1), 387--422.

Black, Fisher. (1995). 'Interest Rates as Options', Journal of Finance 50, 1371-1376 .

Canova, Fabio. (2005). 'The transmission of US shocks to Latin America', Journal of Applied Econometrics 20(2), 229--251.

Chang, Chun, Liu, Zheng and Spiegel, Mark M. (2015). 'Capital controls and optimal Chinese monetary policy', Journal of Monetary Economics $74,1--15$.

Colombo, Valentina. (2013). 'Economic policy uncertainty in the US: Does it matter for the Euro area?', Economics Letters 121(1), 39--42. 
Dedola, Luca, Karadi, Peter and Lombardo, Giovanni. (2013). 'Global implications of national unconventional policies', Journal of Monetary Economics 60(1), 66--85.

Evans, Charles L and Marshall, David A. (2009). 'Fundamental Economic Shocks and the Macroeconomy', Journal of Money, Credit and Banking 41(8), 1515--1555.

Fernald, John, Spiegel, Mark M and Swanson, Eric T. (2014). 'Monetary policy effectiveness in China: evidence from a FAVAR model', Journal of International Money and Finance.

Fleming, Sam. (2016). 'Yellen warns global turbulence could hit growth', Financial Times .

Glick, Reuven and Hutchison, Michael. (2013). 'China's financial linkages with Asia and the global financial crisis', Journal of International Money and Finance 39, 186--206.

Gürkaynak, Refet S, Sack, Brian and Wright, Jonathan H. (2007). 'The US Treasury yield curve: 1961 to the present', Journal of Monetary Economics 54(8), 2291--2304.

He, Qing, Leung, Pak-Ho and Chong, Terence Tai-Leung. (2013). 'Factoraugmented VAR analysis of the monetary policy in China', China Economic Review 25, 88--104.

Kilian, Lutz. (1998). 'Small-sample confidence intervals for impulse response functions', Review of Economics and Statistics 80(2), 218--230. 
Klein, Michael W and Shambaugh, Jay C. (2013), 'Rounding the corners of the policy trilemma: Sources of monetary policy autonomy', Technical report, National Bureau of Economic Research.

Maćkowiak, Bartosz. (2007). 'External shocks, US monetary policy and macroeconomic fluctuations in emerging markets', Journal of Monetary Economics 54(8), 2512--2520.

Madigan, Brian F. (2016a), 'Minutes of the Federal Open Market Committee, April, 2016'.

Madigan, Brian F. (2016b), 'Minutes of the Federal Open Market Committee, January, 2016'.

Martin, Michael F and Morrison, Wayne M. (2008). 'China's 'Hot Money' Problems', CRS Report for Congress, Congressional Research Service.

Miniane, Jacques and Rogers, John H. (2007). 'Capital controls and the international transmission of US money shocks', Journal of Money, Credit and Banking 39(5), 1003--1035.

Mumtaz, Haroon and Surico, Paolo. (2009). 'The Transmission of International Shocks: A Factor-Augmented VAR Approach', Journal of Money, Credit and Banking 41(s1), 71--100.

Neely, Christopher J. (2004). 'The Federal reserve responds to crises: September 11th was not the first', Federal Reserve Bank of St. Louis Review 86(March/April 2004). 
Prasad, Eswar and Wei, Shang-Jin. (2007), The Chinese approach to capital inflows: patterns and possible explanations, in 'Capital Controls and Capital Flows in Emerging Economies: Policies, Practices and Consequences', University of Chicago Press, pp. 421--480.

Prasad, Eswar and Ye, Lei Sandy. (2012). 'The Renminbi's role in the global monetary system', Brookings Institution Report .

Stock, James H and Watson, Mark W. (2002). 'Macroeconomic forecasting using diffusion indexes', Journal of Business 83 Economic Statistics 20(2), 147--162.

World Bank. (2014). '2011 International comparison program summary results release: Compares the real size of the world economies'.

Wu, Jing Cynthia and Xia, Fan Dora. (2016). 'Measuring the macroeconomic impact of monetary policy at the zero lower bound', Journal of Money, Credit and Banking 48(2-3), 253--291. 


\section{Appendix}

A. Figures

A.1. U.S. Monetary Policy and Policy Uncertainty Measures

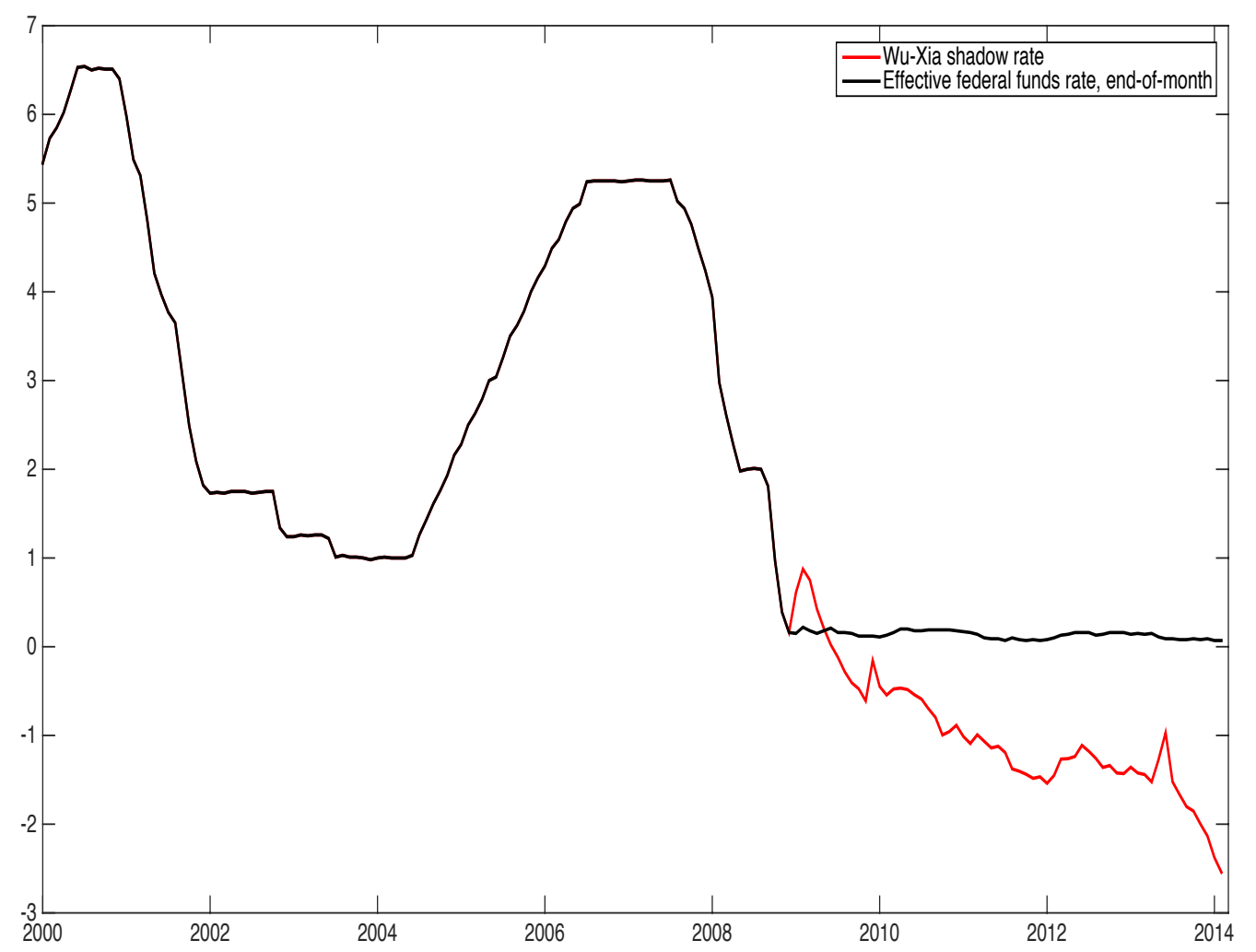

Figure 1: The Wu-Xia shadow rate compared with the effective federal funds rate.

Source: Board of Governors of the Federal Reserve System and Wu and Xia (2016) 


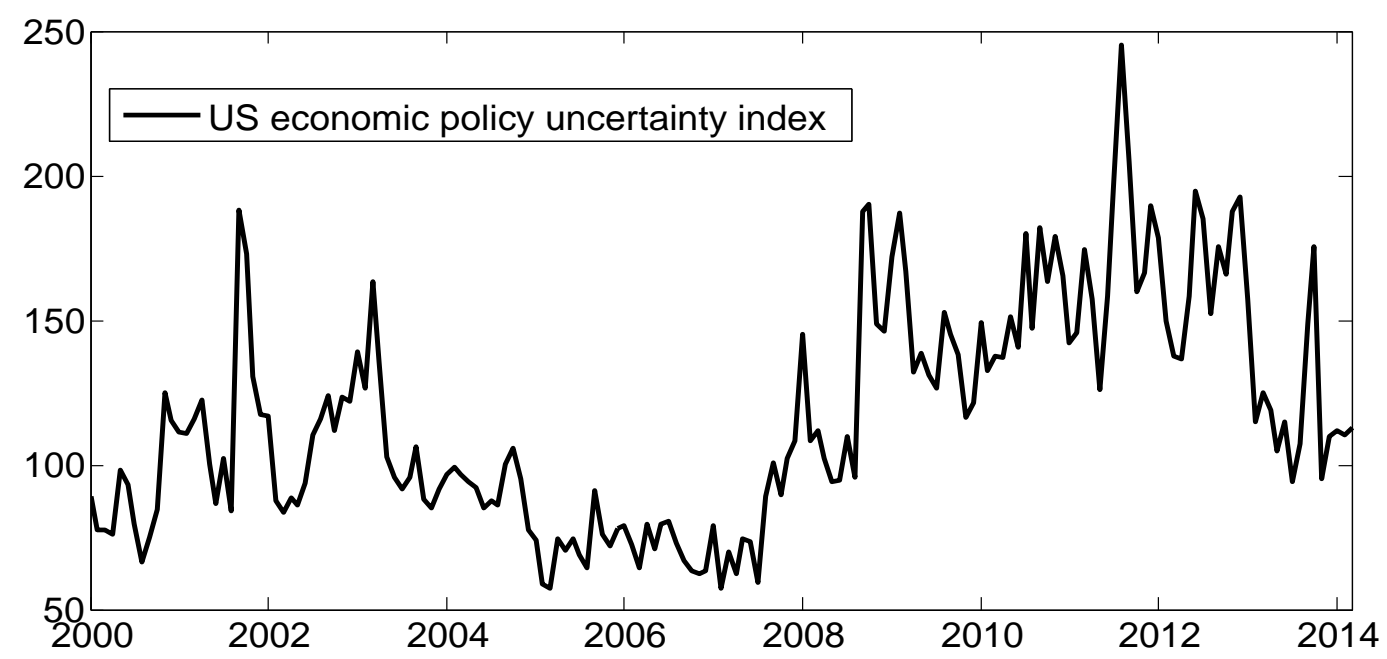

Figure 2: Monthly U.S. Economic Policy Uncertainty Index.

Source: Baker, Bloom and Davis (2015) 


\section{A.2. Impulse Responses at the Zero Lower Bound}

Impulse Responses to U.S. Monetary Policy Shock at the ZLB
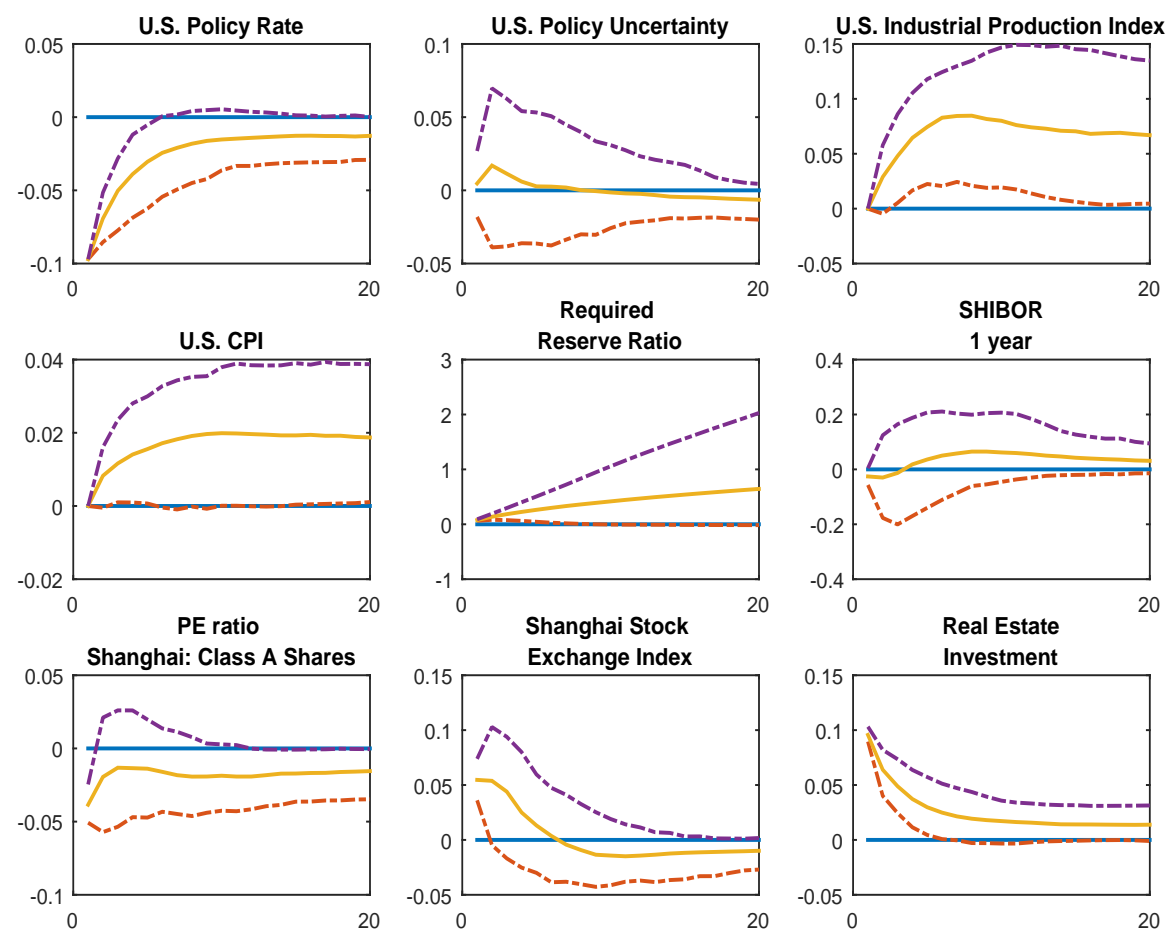

Figure 3: Impulse Responses to U.S. Monetary Policy Shock at the ZLB Note: Impulse responses to a monetary policy shock from 1 to 20 months at the zero lower bound, estimated using data from January 2009 to February 2014. The solid lines are the bootstrap median, and the dashed lines are $90 \%$ bootstrap confidence intervals. The monetary policy shock corresponds to a decrease in the $\mathrm{Wu}$-Xia shadow rate of 25 basis points. 
Impulse Responses to U.S. Monetary Policy Shock at the ZLB
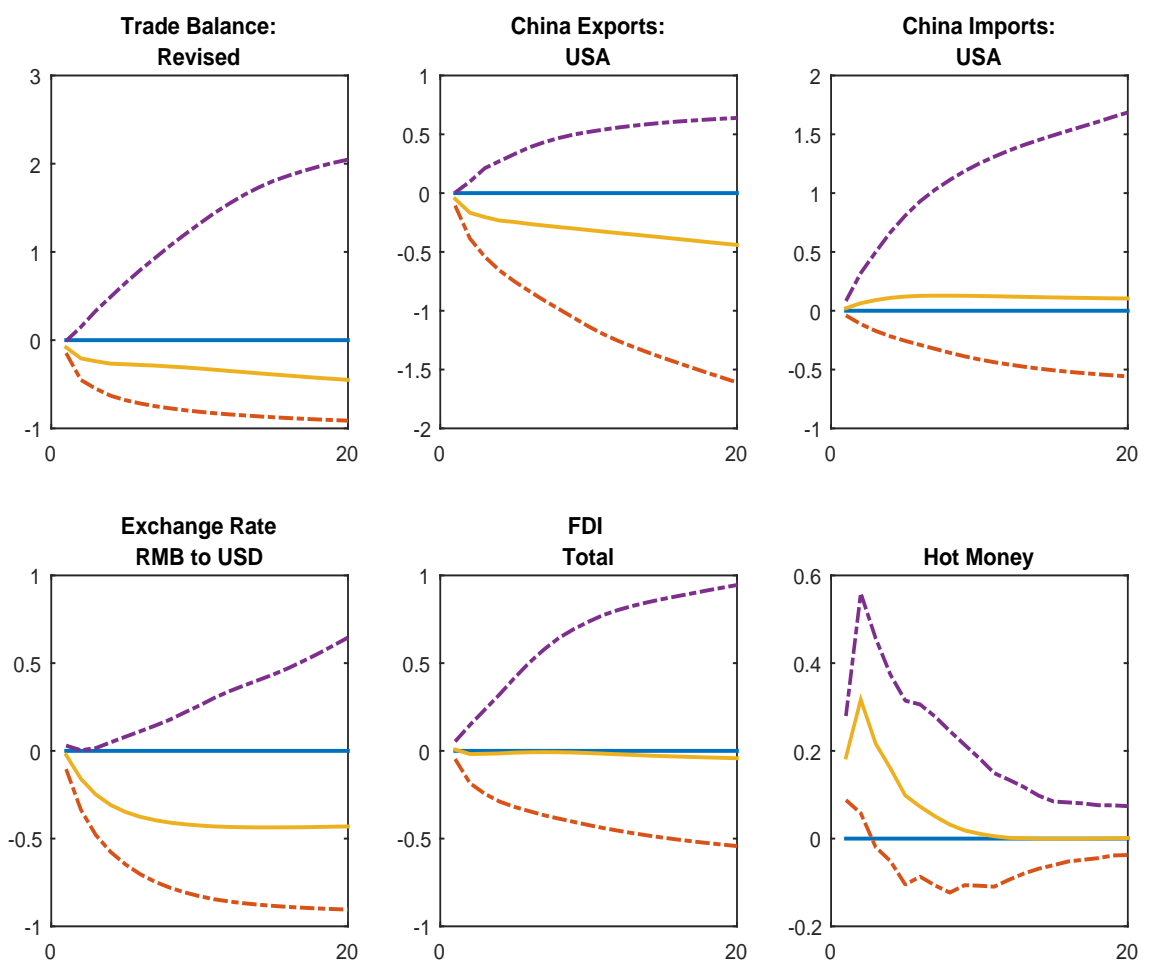

Figure 4: Impulse Responses to U.S. Monetary Policy Shock at the ZLB Note: Impulse responses to a monetary policy shock from 1 to 20 months at the zero lower bound, estimated using data from January 2009 to February 2014. The solid lines are the bootstrap median, and the dashed lines are $90 \%$ bootstrap confidence intervals. The monetary policy shock corresponds to a decrease in the $\mathrm{Wu}$-Xia shadow rate of 25 basis points. 
Impulse Responses to U.S. Policy Uncertainty Shock at the ZLB
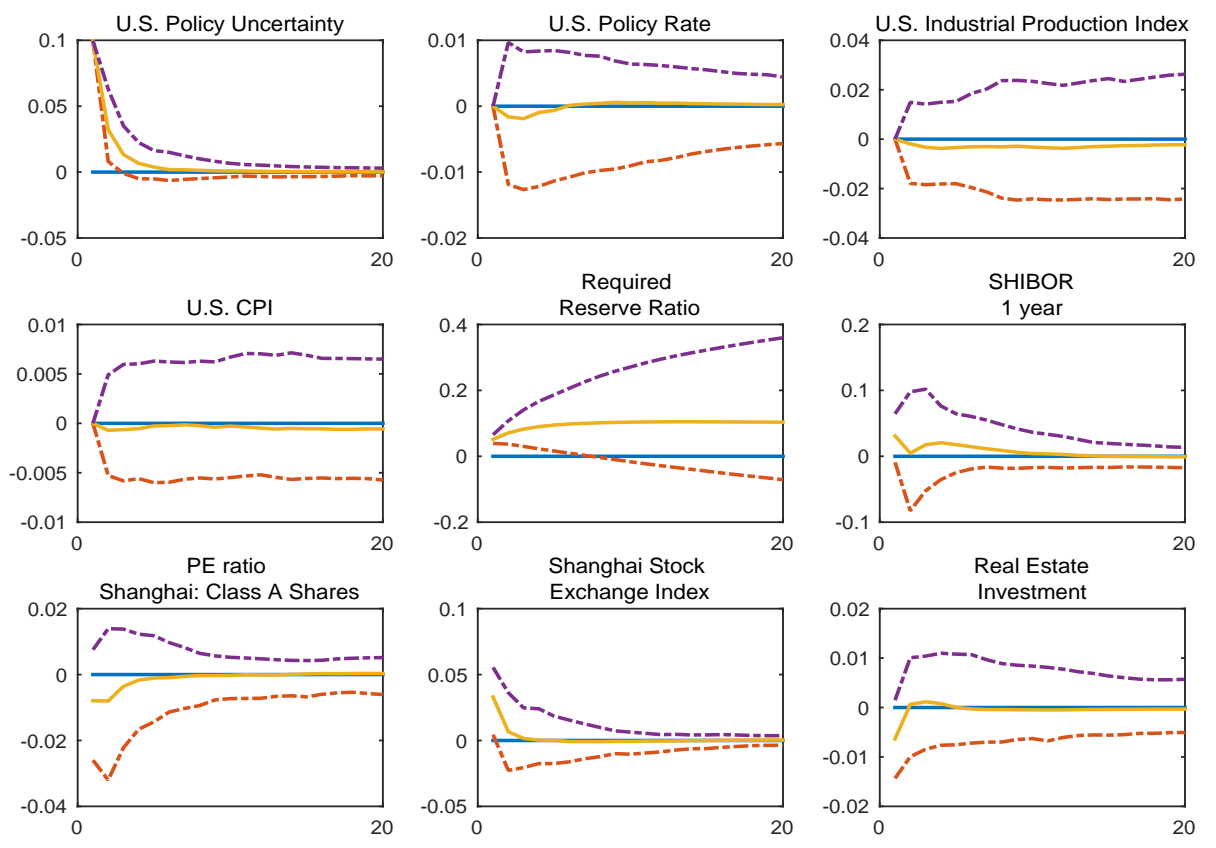

Figure 5: Impulse Responses to U.S. Policy Uncertainty Shock at the ZLB Note: Impulse responses to a policy uncertainty shock from 1 to 20 months at the zero lower bound, estimated using data from January 2009 to February 2014. The solid lines are the bootstrap median, and the dashed lines are $90 \%$ bootstrap confidence intervals. The policy uncertainty shock corresponds to an increase in the U.S. policy uncertainty Index of $10 \%$ of the standard deviation. 
Impulse Responses to U.S. Policy Uncertainty Shock at the ZLB
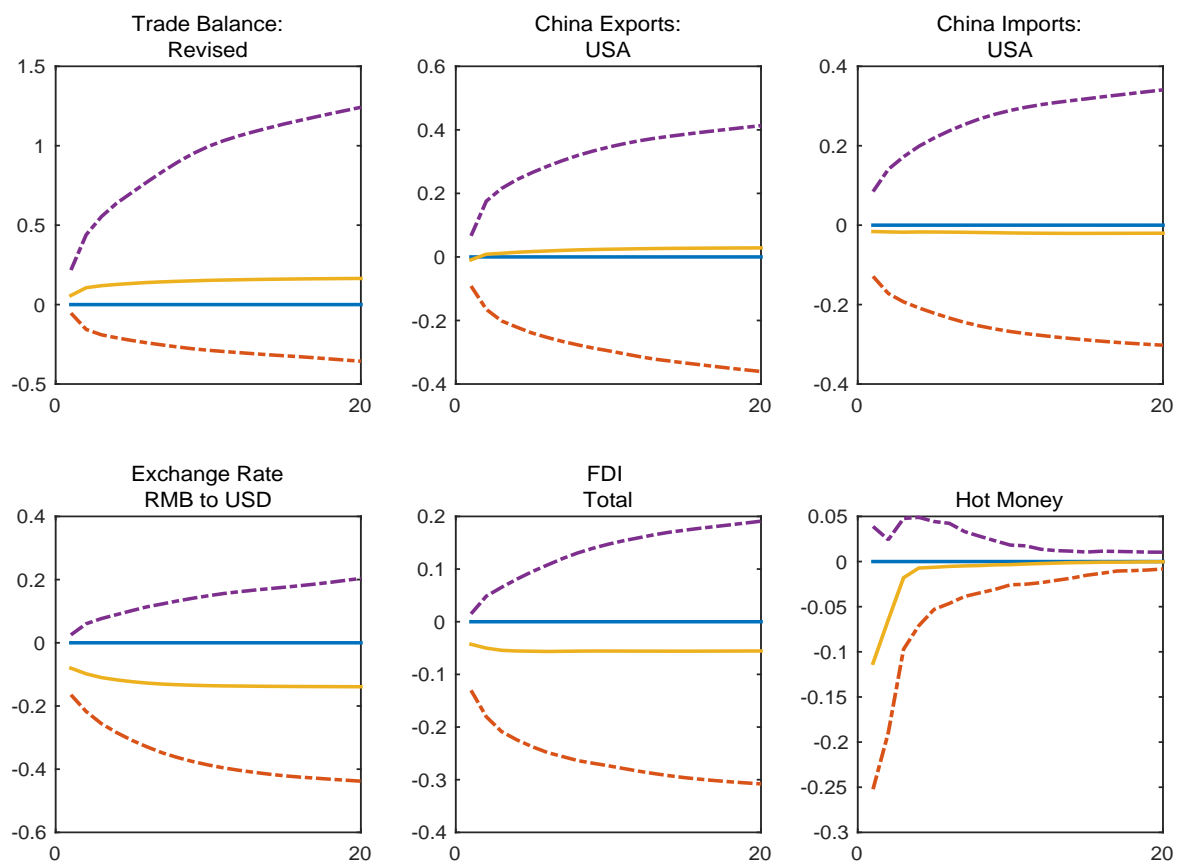

Figure 6: Impulse Responses to U.S. Policy Uncertainty Shock at the ZLB Note: Impulse responses to a policy uncertainty shock from 1 to 20 months at the zero lower bound, estimated using data from January 2009 to February 2014. The solid lines are the bootstrap median, and the dashed lines are $90 \%$ bootstrap confidence intervals. The policy uncertainty shock corresponds to an increase in the U.S. policy uncertainty index of $10 \%$ of the standard deviation. 


\title{
A.3. Impulse Responses before the Zero Lower Bound
}

\author{
Impulse Responses to U.S. Monetary Policy Shock before the ZLB
}
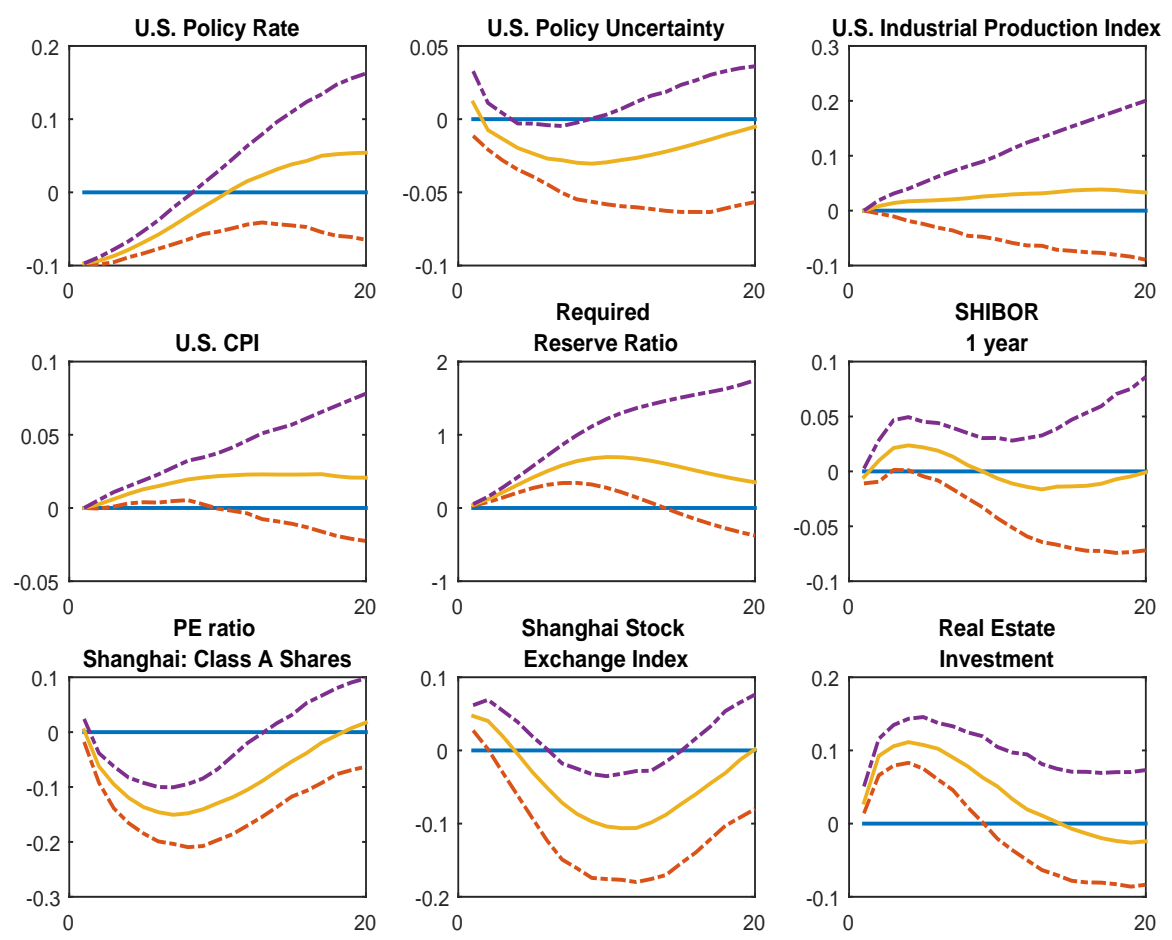

Figure 7: Impulse Responses to U.S. Monetary Policy Shock before the ZLB Note: Impulse responses to a monetary policy shock from 1 to 20 months before the zero lower bound is binding, estimated using data from January 2000 to December 2008. The solid lines are the bootstrap median, and the dashed lines are $90 \%$ bootstrap confidence intervals. The monetary policy shock corresponds to a decrease in the effective federal funds rate of 25 basis points. 
Impulse Responses to U.S. Monetary Policy Shock before the ZLB
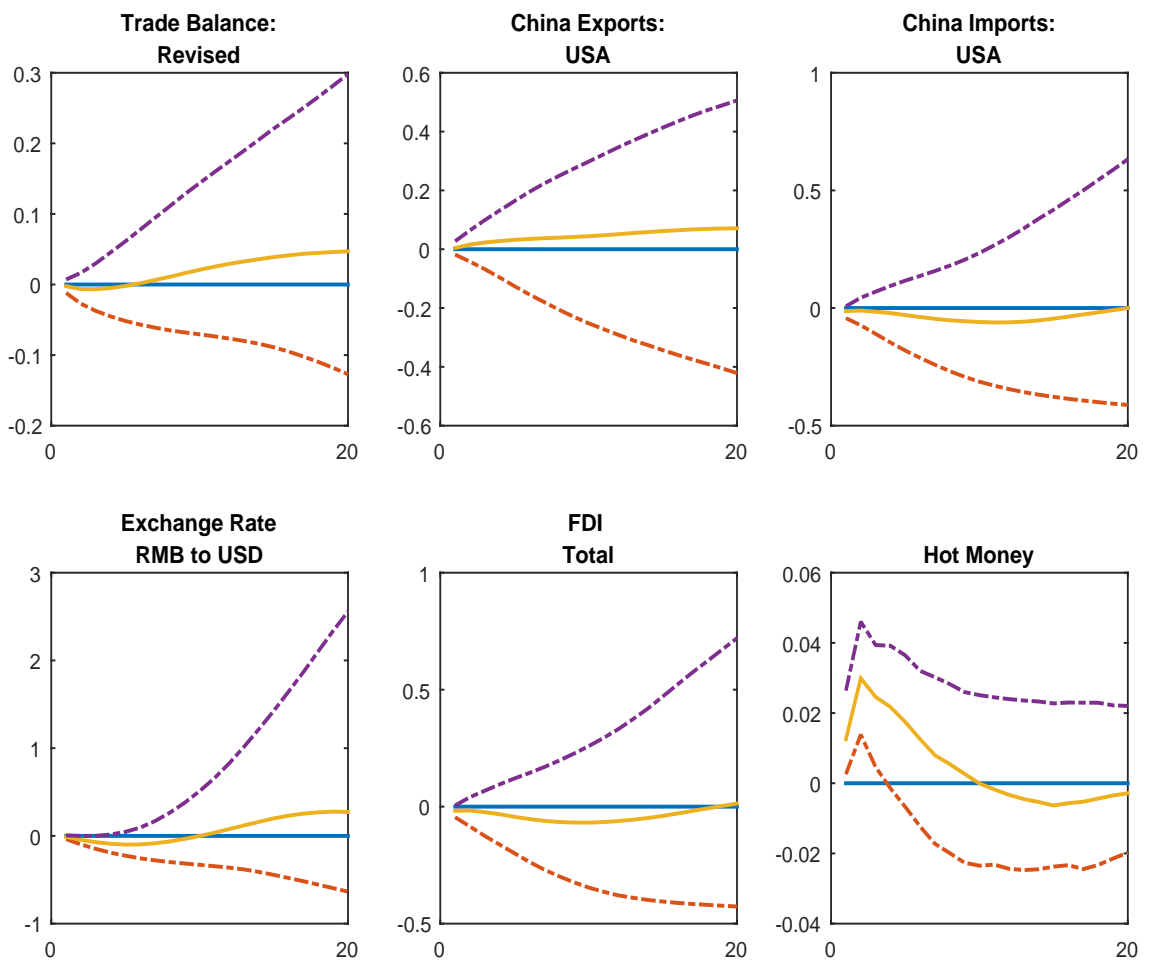

Figure 8: Impulse Responses to U.S. Monetary Policy Shock before the ZLB Note: Impulse responses to a monetary policy shock from 1 to 20 months before the zero lower bound is binding, estimated using data from January 2000 to December 2008. The solid lines are the bootstrap median, and the dashed lines are $90 \%$ bootstrap confidence intervals. The monetary policy shock corresponds to a decrease in the effective federal funds rate of 25 basis points. 
Impulse Responses to U.S. Policy Uncertainty Shock before the ZLB
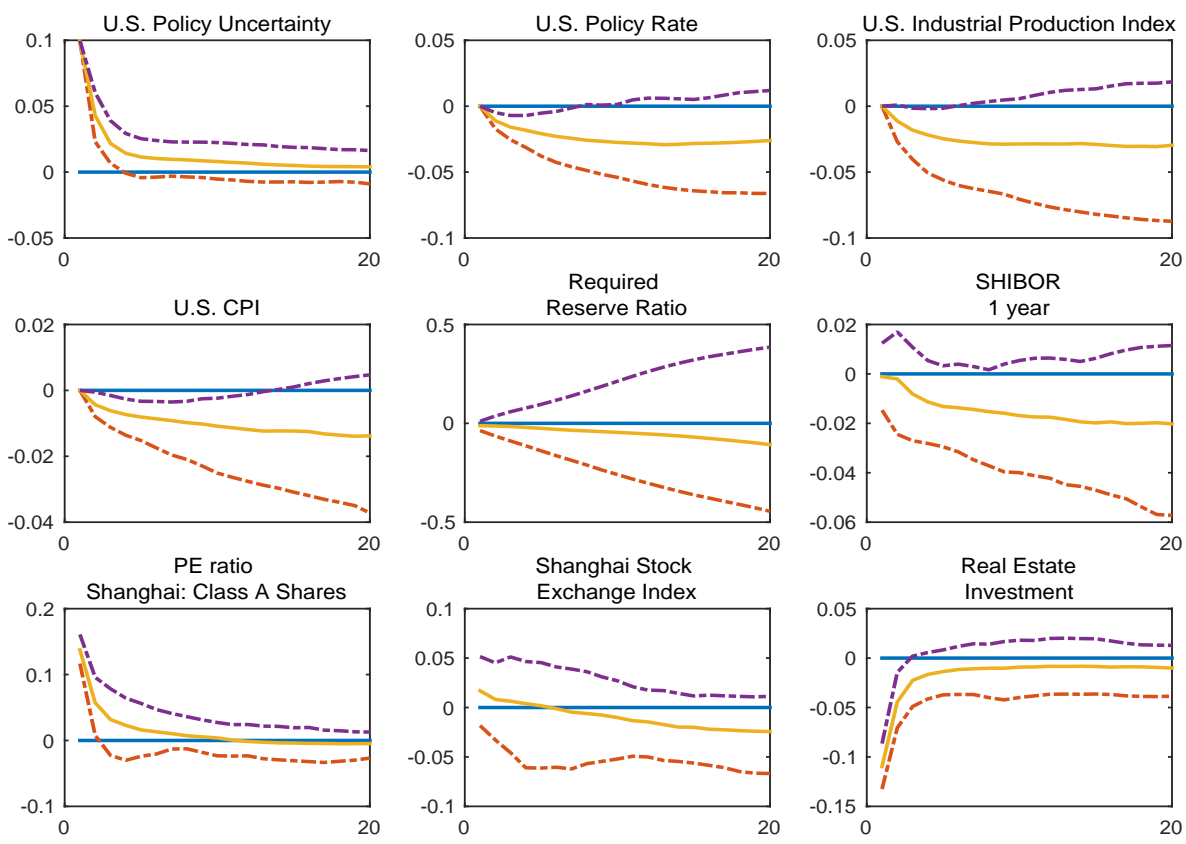

Figure 9: Impulse Responses to U.S. Policy Uncertainty Shock before the ZLB

Note: Impulse responses to a policy uncertainty shock from 1 to 20 months before the zero lower bound is binding, estimated using data from January 2000 to December 2008. The solid lines are the bootstrap median, and the dashed lines are $90 \%$ bootstrap confidence intervals. The policy uncertainty shock corresponds to an increase in the U.S. policy uncertainty index of $10 \%$ of the standard deviation. 
Impulse Responses to U.S. Policy Uncertainty Shock before the ZLB
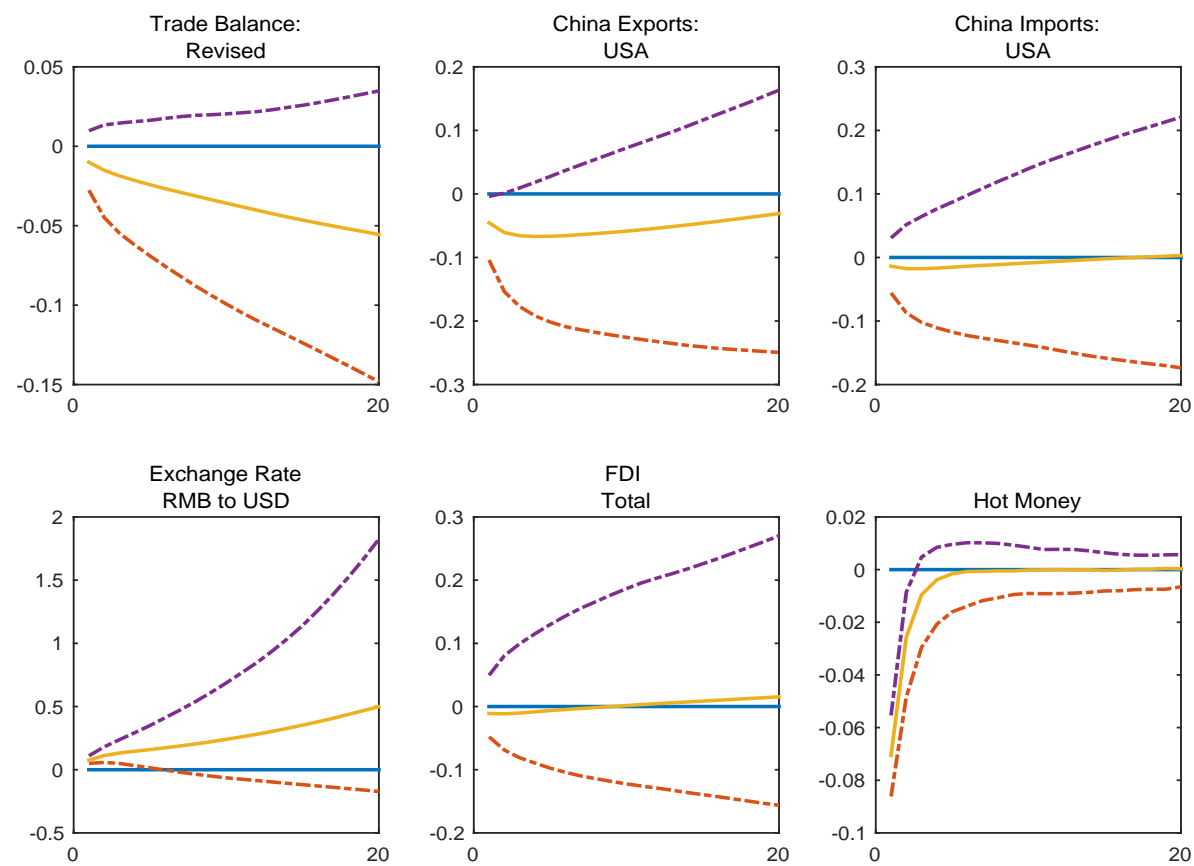

Figure 10: Impulse Responses to U.S. Policy Uncertainty Shock before the ZLB

Note: Impulse responses to a policy uncertainty shock from 1 to 20 months before the zero lower bound is binding, estimated using data from January 2000 to December 2008. The solid lines are the bootstrap median, and the dashed lines are $90 \%$ bootstrap confidence intervals. The policy uncertainty shock corresponds to an increase in the U.S. policy uncertainty index of $10 \%$ of the standard deviation. 


\section{B. Tables}

Table 1: Variance Decomposition Ratio (MP/PU) at the ZLB

\begin{tabular}{|l|lll|}
\hline \hline \multicolumn{1}{|c|}{ Variables } & $3 \mathrm{~m}$ & $6 \mathrm{~m}$ & $12 \mathrm{~m}$ \\
\hline Required Reserve Ratio & 1.22 & 1.56 & 1.80 \\
SHIBOR 1 year & 2.82 & 3.22 & 3.50 \\
PE ratio Shanghai: Class A Shares & 5.98 & 3.53 & 2.66 \\
Shanghai Stock Exchange Index & 1.10 & 1.23 & 1.34 \\
Real Estate Investment & 52.33 & 62.56 & 57.12 \\
Trade Balance: Revised & 0.38 & 0.47 & 0.56 \\
China Exports: USA & 10.58 & 11.17 & 11.86 \\
China Imports: USA & 0.26 & 0.31 & 0.39 \\
Exchange Rate RMB to USD & 0.14 & 0.24 & 0.34 \\
FDI Total & 0.39 & 0.62 & 0.84 \\
Hot Money & 1.04 & 1.24 & 1.38 \\
\hline \hline
\end{tabular}

Note:"MP" and "PU" represent monetary policy shock and policy uncertainty shock, respectively. The "Variance Decomposition Ratio" represents the ratio between the percentage of $k$-month-ahead forecast errors that monetary policy shocks account for and that policy uncertainty shocks account for. The forecast horizon $k$ we report takes the values 3,6 , and 12 . 


\section{Data Description}

\section{C.1. Data Description: Chinese Variables}

All series are taken from CEIC China Premium Database. All series are in monthly frequencies and data spans are shown. Missing data are imputed by utilizing the EM algorithm as in Stock and Watson (2002). Each variable is assumed to be either fast moving or slow moving for the purpose of FA-VAR estimation. Seasonality adjustment is performed using the U.S. Census Bureau's X-13 program: $\mathrm{SA}=$ seasonally adjusted, $\mathrm{NS}=$ no seasonal adjustment. The transformations are $\Delta$-first difference; $l n$-logarithm; $\Delta l n$-first difference of logarithm; none-no transformation.

Real Activities

\begin{tabular}{|c|c|c|c|c|c|}
\hline 1. & Retail Sales of Consumer Goods: Total & $1999 / 12-2014 / 02$ & Slow & $\mathrm{SA}$ & $\Delta l n$ \\
\hline 2 . & Gross Industrial Output & $2003 / 03-2012 / 05$ & Slow & $\mathrm{SA}$ & $\Delta l n$ \\
\hline 3. & Industrial Sales & $1999 / 12-2014 / 02$ & Slow & $\mathrm{SA}$ & $\Delta l n$ \\
\hline 4. & Industrial Sales: Delivery Value for Export & $1999 / 12-2014 / 02$ & Slow & $\mathrm{SA}$ & $\Delta l n$ \\
\hline 5. & Industrial Sales: Light Industry & $1999 / 12-2014 / 02$ & Slow & $\mathrm{SA}$ & $\Delta l n$ \\
\hline 6. & Industrial Sales: Heavy Industry & $1999 / 12-2014 / 02$ & Slow & $\mathrm{SA}$ & $\Delta l n$ \\
\hline 7. & Industrial Sales Nominal Growth: Light Industry & $1999 / 12-2013 / 02$ & Slow & $\mathrm{SA}$ & none \\
\hline 8. & Industrial Sales Nominal Growth: Heavy Industry & $1999 / 12-2013 / 02$ & Slow & $\mathrm{SA}$ & none \\
\hline 9. & Industrial Sales Nominal Growth: Delivery Value for Export & 2001/03-2013/12 & Slow & $\mathrm{SA}$ & none \\
\hline 10. & Industrial Sales Nominal Growth: Same Period Last Year & $1999 / 12-2014 / 02$ & Slow & $\mathrm{SA}$ & none \\
\hline 11. & Macro Index & $1999 / 12-2014 / 02$ & Fast & SA & $\Delta l n$ \\
\hline 12 . & Production of Primary Energy: Electricity & $1999 / 12-2014 / 02$ & Slow & SA & $\Delta l n$ \\
\hline 13. & Transport: Passenger Traffic & $1999 / 12-2014 / 02$ & Slow & SA & $\Delta l n$ \\
\hline 14. & Automobile Sales & $1999 / 12-2014 / 02$ & Slow & $\mathrm{SA}$ & $\Delta l n$ \\
\hline 15. & Automobile Sales: Domestic Made & $1999 / 12-2014 / 02$ & Slow & $\mathrm{SA}$ & $\Delta l n$ \\
\hline 16. & Automobile Production & $1999 / 12-2014 / 02$ & Slow & $\mathrm{SA}$ & $\Delta l n$ \\
\hline 17. & Automobile Production: Domestic Made & $1999 / 12-2014 / 02$ & Slow & SA & $\Delta l n$ \\
\hline 18. & Steel Production: Iron Ore & $1999 / 12-2014 / 02$ & Slow & SA & $\Delta l n$ \\
\hline 19. & Steel Production: Pig Iron & $1999 / 12-2014 / 02$ & Slow & SA & $\Delta l n$ \\
\hline 20. & Steel Production: Coke & $1999 / 12-2014 / 02$ & Slow & SA & $\Delta l n$ \\
\hline 21. & Steel Production: Ferroalloy & $1999 / 12-2014 / 02$ & Slow & $\mathrm{SA}$ & $\Delta l n$ \\
\hline 22. & Steel Production: Crude Steel & $1999 / 12-2014 / 02$ & Slow & $\mathrm{SA}$ & $\Delta l n$ \\
\hline 23. & Steel Production: Steel Product & $1999 / 12-2014 / 02$ & Slow & SA & $\Delta l n$ \\
\hline 24. & Petro Production: Natural Gas & $1999 / 12-2014 / 02$ & Slow & $\mathrm{SA}$ & $\Delta l n$ \\
\hline 25. & Petro Production: Crude Oil & $1999 / 12-2014 / 02$ & Slow & $\mathrm{SA}$ & $\Delta l n$ \\
\hline 26. & Petro Production: Crude Oil Processed & $1999 / 12-2014 / 02$ & Slow & SA & $\Delta l n$ \\
\hline 27. & Petro Production: Oil Product: Coal Oil & $1999 / 12-2014 / 02$ & Slow & $\mathrm{SA}$ & $\Delta l n$ \\
\hline 28. & Petro Production: Oil Product: Gasoline & $1999 / 12-2014 / 02$ & Slow & $\mathrm{SA}$ & $\Delta l n$ \\
\hline 29. & Petro Production: Oil Product: Diesel Oil & $1999 / 12-2014 / 02$ & Slow & $\mathrm{SA}$ & $\Delta l n$ \\
\hline 30. & Petro Production: Fuel Oil & $1999 / 12-2014 / 02$ & Slow & $\mathrm{SA}$ & $\Delta l n$ \\
\hline 31. & Product Inventory & $1999 / 12-2014 / 02$ & Slow & $\mathrm{SA}$ & $\Delta l n$ \\
\hline 32. & Purchasing Managers' Index: Manufacturing & $2005 / 03-2014 / 02$ & Slow & $\mathrm{SA}$ & none \\
\hline 33. & Purchasing Managers' Index: New Export Orders & $2005 / 03-2014 / 02$ & Slow & $\mathrm{SA}$ & none \\
\hline
\end{tabular}


Investments

\begin{tabular}{|c|c|c|c|c|c|}
\hline 34. & Fixed Assets Investment & $1999 / 12-2014 / 02$ & Slow & SA & $\Delta l n$ \\
\hline 35 . & FDI Utilized: Joint Ventures & $1999 / 12-2014 / 02$ & Slow & SA & $\Delta l n$ \\
\hline 36. & FDI Utilized: Total & $1999 / 12-2014 / 02$ & Slow & SA & $\Delta l n$ \\
\hline 37. & FDI Utilized: Cooperative Ventures & $1999 / 12-2014 / 02$ & Slow & SA & $\Delta l n$ \\
\hline 38. & FDI Utilized: Foreign Enterprises & $1999 / 12-2014 / 02$ & Slow & SA & $\Delta l n$ \\
\hline
\end{tabular}

International Accounts

\begin{tabular}{|c|c|c|c|c|c|}
\hline 39. & Foreign Reserve & $1999 / 12-2014 / 02$ & Fast & $\mathrm{SA}$ & $\Delta l n$ \\
\hline 40. & Financial Institutions CF: Position for Forex Purchase & $1999 / 12-2014 / 02$ & Fast & $\mathrm{SA}$ & $\Delta l n$ \\
\hline 41. & Exports (fob) & $1999 / 12-2014 / 02$ & Slow & $\mathrm{SA}$ & $\Delta l n$ \\
\hline 42 . & Imports (cif) & $1999 / 12-2014 / 02$ & Slow & $\mathrm{SA}$ & $\Delta l n$ \\
\hline 43. & Trade Balance & $1999 / 12-2014 / 02$ & Slow & SA & none \\
\hline 44. & Export FOB: Revised & $1999 / 12-2014 / 02$ & Slow & $\mathrm{SA}$ & $\Delta l n$ \\
\hline 45. & Import CIF: Revised & $1999 / 12-2014 / 02$ & Slow & $\mathrm{SA}$ & $\Delta l n$ \\
\hline 46. & Trade Balance: Revised & $1999 / 12-2014 / 02$ & Slow & $\mathrm{SA}$ & $\Delta$ \\
\hline 47. & China Exports: USA & $1999 / 12-2014 / 02$ & Slow & $\mathrm{SA}$ & $\Delta l n$ \\
\hline 48. & China Imports: USA & $1999 / 12-2014 / 02$ & Slow & $\mathrm{SA}$ & $\Delta l n$ \\
\hline 49. & Monetary Authority: Asset: Total & $1999 / 12-2014 / 02$ & Fast & NS & $\Delta l n$ \\
\hline 50. & Monetary Authority: Asset: Foreign Asset: Foreign Exchange & $1999 / 12-2014 / 02$ & Fast & NS & $\Delta l n$ \\
\hline 51. & Monetary Authority: Asset: Foreign Asset: Gold & $1999 / 12-2014 / 02$ & Fast & NS & $\Delta l n$ \\
\hline 52. & Monetary Authority: Asset: Foreign Asset: Foreign Exchange & $1999 / 12-2014 / 02$ & Fast & NS & $\Delta l n$ \\
\hline 53. & Monetary Authority: Liab: Reserve Money & $1999 / 12-2014 / 02$ & Fast & NS & $\Delta l n$ \\
\hline 54. & Monetary Authority: Liab: Reserve Money: Currency Issue & $1999 / 12-2014 / 02$ & Fast & NS & $\Delta l n$ \\
\hline 55 . & Hot Money & $2000 / 01-2014 / 02$ & Fast & $\mathrm{SA}$ & none \\
\hline
\end{tabular}

Exchange Rates and Swaps

\begin{tabular}{|c|c|c|c|c|c|}
\hline 56. & Foreign Exchange Rate: PBOC: Month End: RMB to USD & $1999 / 12-2014 / 02$ & Fast & NS & none \\
\hline 57. & Currency Swap: USD: 1 Week: Bid & 2006/09-2014/02 & Fast & NS & none \\
\hline 58. & Currency Swap: USD: 1 Week: Offer & 2006/09-2014/02 & Fast & NS & none \\
\hline 59. & Currency Swap: USD: 1 Month: Bid & 2006/09-2014/02 & Fast & NS & none \\
\hline 60. & Currency Swap: USD: 1 Month: Offer & 2006/09-2014/02 & Fast & NS & none \\
\hline 61. & Currency Swap: USD: 3 Month: Bid & 2006/09-2014/02 & Fast & NS & none \\
\hline 62. & Currency Swap: USD: 3 Month: Offer & 2006/09-2014/02 & Fast & NS & none \\
\hline 63. & Currency Swap: USD: 6 Month: Bid & 2006/09-2014/02 & Fast & NS & none \\
\hline 64. & Currency Swap: USD: 6 Month: Offer & 2006/09-2014/02 & Fast & NS & none \\
\hline 65. & Currency Swap: USD: 1 Year: Offer & 2006/09-2014/02 & Fast & NS & none \\
\hline 66. & Currency Swap: USD: 1 Year: Bid & 2006/09-2014/02 & Fast & NS & none \\
\hline
\end{tabular}

Government 


\begin{tabular}{|c|c|c|c|c|c|}
\hline 67. & Government Expenditure & $1999 / 12-2014 / 02$ & Slow & SA & $\Delta l n$ \\
\hline 68. & Govt Revenue & $1999 / 12-2014 / 02$ & Slow & $\mathrm{SA}$ & $\Delta l n$ \\
\hline 69. & Govt Revenue: Tax & $1999 / 12-2014 / 02$ & Slow & $\mathrm{SA}$ & $\Delta l n$ \\
\hline 70. & Govt Revenue: Tax: Tariffs & $1999 / 12-2014 / 02$ & Slow & $\mathrm{SA}$ & $\Delta l n$ \\
\hline 71. & Govt Revenue: Tax: Value Added & $1999 / 12-2014 / 02$ & Slow & SA & $\Delta l n$ \\
\hline 72 . & Govt Revenue: Tax: Operation & $1999 / 12-2014 / 02$ & Slow & SA & $\Delta l n$ \\
\hline 73. & Govt Revenue: Tax: Security Stamp & $1999 / 12-2014 / 02$ & Slow & $\mathrm{SA}$ & $\Delta l n$ \\
\hline
\end{tabular}

Money Supply and Credits

\begin{tabular}{|c|c|c|c|c|c|}
\hline 74. & Money Supply M0 & $1999 / 12-2014 / 02$ & Fast & $\mathrm{SA}$ & $\Delta \ln$ \\
\hline 75 . & Money Supply M1 & $1999 / 12-2014 / 02$ & Fast & SA & $\Delta l n$ \\
\hline 76. & Money Supply M1: Demand Deposit & $1999 / 12-2014 / 02$ & Fast & SA & $\Delta l n$ \\
\hline 77 . & Money Supply M2 & $1999 / 12-2014 / 02$ & Fast & SA & $\Delta l n$ \\
\hline 78. & Money Supply M2: Quasi Money: Saving Deposit & $1999 / 12-2014 / 02$ & Fast & SA & $\Delta l n$ \\
\hline 79 . & Money Supply M2: Quasi Money: Time Deposit & $1999 / 12-2014 / 02$ & Fast & SA & $\Delta l n$ \\
\hline 80 . & Money Supply M2: Quasi Money: Other Deposit & $1999 / 12-2014 / 02$ & Fast & SA & $\Delta l n$ \\
\hline 81. & Loan & $1999 / 12-2014 / 02$ & Slow & SA & $\Delta l n$ \\
\hline 82. & Required Reserve Ratio & $1999 / 12-2014 / 02$ & Slow & NS & none \\
\hline
\end{tabular}

Interest Rates

\begin{tabular}{|c|c|c|c|c|c|}
\hline 83. & Loan Rate (1yr) & $1999 / 12-2014 / 02$ & Slow & NS & none \\
\hline 84. & Nominal Lending Rate: Medium and Long Term: 3 Year or Less & $1999 / 12-2014 / 02$ & Slow & NS & none \\
\hline 85. & Nominal Lending Rate: Medium and Long Term: 5 Year or Less & $1999 / 12-2014 / 02$ & Slow & NS & none \\
\hline 86. & Nominal Lending Rate: Medium and Long Term: Over 5 Year & $1999 / 12-2014 / 02$ & Slow & NS & none \\
\hline 87. & $\begin{array}{l}\text { Nominal Lending Rate: Housing Loan (Reserve Fund A/C): } 5 \text { Yr or } \\
\text { Less }\end{array}$ & $1999 / 12-2014 / 02$ & Slow & NS & none \\
\hline 88. & $\begin{array}{l}\text { Nominal Lending Rate: Housing Loan (Reserve Fund A/C): Over } 5 \\
\text { Year }\end{array}$ & $1999 / 12-2014 / 02$ & Slow & NS & none \\
\hline 89. & Central Bank Benchmark Interest Rate: Loans to FI: 1 Year & $1999 / 12-2014 / 02$ & Slow & NS & none \\
\hline 90. & Central Bank Benchmark Interest Rate: Loans to FI: 6 Month or Less & $1999 / 12-2014 / 02$ & Slow & NS & none \\
\hline 91. & Central Bank Benchmark Interest Rate: Loans to FI: 3 Month or Less & $1999 / 12-2014 / 02$ & Slow & NS & none \\
\hline 92. & Household Savings Deposits Rate: Time: 3 Month & $1999 / 12-2014 / 02$ & Slow & NS & none \\
\hline 93. & Household Savings Deposits Rate: Time: 6 Month & $1999 / 12-2014 / 02$ & Slow & NS & none \\
\hline 94. & Household Savings Deposits Rate: Time: 1 Year & $1999 / 12-2014 / 02$ & Slow & NS & none \\
\hline 95. & Household Savings Deposits Rate: Time: 2 Year & $1999 / 12-2014 / 02$ & Slow & NS & none \\
\hline 96. & Household Savings Deposits Rate: Time: 3 Year & $1999 / 12-2014 / 02$ & Slow & NS & none \\
\hline 97. & Household Savings Deposits Rate: Time: 5 Year & $1999 / 12-2014 / 02$ & Slow & NS & none \\
\hline 98. & Household Savings Deposits Rate: Demand & $1999 / 12-2014 / 02$ & Slow & NS & none \\
\hline 99. & Reloan Interest Rates: within 20 days & $1999 / 12-2014 / 02$ & Slow & NS & none \\
\hline 100. & Reloan Interest Rates: within 3 months & $1999 / 12-2014 / 02$ & Slow & NS & none \\
\hline 101. & Reloan Interest Rates: within 6 months & $1999 / 12-2014 / 02$ & Slow & NS & none \\
\hline 102. & Reloan Interest Rrates: 1 year & $1999 / 12-2014 / 02$ & Slow & NS & none \\
\hline 103. & Shanghai Interbank Offered Rate(SHIBOR): 1 day & $2006 / 10-2014 / 02$ & Fast & NS & none \\
\hline
\end{tabular}


104. Shanghai Interbank Offered Rate(SHIBOR): 1 month

105. Shanghai Interbank Offered Rate(SHIBOR): 3 months

106. Shanghai Interbank Offered Rate(SHIBOR): 6 months

107. Shanghai Interbank Offered Rate(SHIBOR): 1 year

108. Private Lending Rate: Wenzhou: Monthly Average

109. Bond index: Inter-bank: Treasury Bonds: Short-term

110. Bond Index: Interbank: Treasury Bond: Medium Term

111. Bond Index: Interbank: Treasury Bond: Long Term

112. Bond Index: Interbank: Policy Financial Bond

$\begin{array}{llll}2006 / 10-2014 / 02 & \text { Fast } & \text { NS } & \text { none } \\ 2006 / 10-2014 / 02 & \text { Fast } & \text { NS } & \text { none } \\ 2006 / 10-2014 / 02 & \text { Fast } & \text { NS } & \text { none } \\ 2006 / 10-2014 / 02 & \text { Fast } & \text { NS } & \text { none } \\ 2012 / 06-2014 / 02 & \text { Fast } & \text { NS } & \text { none } \\ 2009 / 06-2014 / 02 & \text { Fast } & \text { NS } & \text { none } \\ 2009 / 06-2014 / 02 & \text { Fast } & \text { NS } & \text { none } \\ 2009 / 06-2014 / 02 & \text { Fast } & \text { NS } & \text { none } \\ 2009 / 06-2014 / 02 & \text { Fast } & \text { NS } & \text { none }\end{array}$

Stock Markets

\begin{tabular}{|c|c|c|c|c|c|}
\hline 113. & Shanghai Stock Exchange Index & $1999 / 12-2014 / 02$ & Fast & NS & none \\
\hline 114. & Index: Shenzhen Stock Exchange: Composite & $1999 / 12-2014 / 02$ & Fast & NS & none \\
\hline 115. & Price to Earnings Ratio-Shanghai Stock Exchange: All shares & $1999 / 12-2014 / 02$ & Fast & NS & none \\
\hline 116. & Price to Earnings Ratio-Shanghai Stock Exchange: Class-A shares & $1999 / 12-2014 / 02$ & Fast & NS & none \\
\hline 117. & Price to Earnings Ratio-Shanghai Stock Exchange: financial industry & $2001 / 04-2014 / 02$ & Fast & NS & none \\
\hline 118. & $\begin{array}{l}\text { Price to Earnings Ratio-Shanghai Stock Exchange: the real estate in- } \\
\text { dustry }\end{array}$ & $2001 / 04-2014 / 02$ & Fast & NS & none \\
\hline 119. & $\begin{array}{l}\text { Price to Earnings Ratio-Shanghai Stock Exchange: the construction } \\
\text { industry }\end{array}$ & $2001 / 04-2014 / 02$ & Fast & NS & none \\
\hline 120. & $\begin{array}{l}\text { Price to Earnings Ratio-Shanghai Stock Exchange: Manufacturing in- } \\
\text { dustry }\end{array}$ & $2001 / 04-2014 / 02$ & Fast & NS & none \\
\hline 121. & Price to Earnings Ratio-Shenzhen Stock Exchange: All Share & $1999 / 12-2014 / 02$ & Fast & NS & none \\
\hline 122. & Price to Earnings Ratio-Shenzhen Stock Exchange: Class-A Share & $1999 / 12-2014 / 02$ & Fast & NS & none \\
\hline
\end{tabular}

Price Indices

\begin{tabular}{|c|c|c|c|c|c|}
\hline 123. & Consumer Confidence Index & $1999 / 12-2014 / 02$ & Fast & NS & none \\
\hline 124. & Consumer Expectation Index & $1999 / 12-2014 / 02$ & Fast & NS & none \\
\hline 125. & Consumer Price Index & $1999 / 12-2014 / 02$ & Slow & SA & $\Delta l n$ \\
\hline 126. & CPI: Food & $1999 / 12-2014 / 02$ & Slow & SA & $\Delta l n$ \\
\hline 127. & CPI: Core (excl. Food \& Energy) & $2006 / 03-2014 / 02$ & Slow & SA & $\Delta l n$ \\
\hline 128. & CPI: non-Food & $2005 / 03-2014 / 02$ & Slow & SA & $\Delta l n$ \\
\hline 129. & Coking Coal Price: Monthly average, 36 cities & $1999 / 12-2014 / 02$ & Slow & SA & $\Delta l n$ \\
\hline 130. & Shanghai Futures Exchange: Fuel Price & $2004 / 08-2014 / 02$ & Slow & SA & $\Delta l n$ \\
\hline 131. & Diesel Price: Monthly average & $2004 / 08-2014 / 02$ & Slow & SA & $\Delta l n$ \\
\hline 132. & Pork Price: Lean Meat: 36-city average & $2001 / 03-2014 / 02$ & Slow & SA & $\Delta l n$ \\
\hline 133. & Nanhua Composite Index Monthly & $1999 / 12-2014 / 02$ & Slow & SA & $\Delta l n$ \\
\hline 134. & Nanhua Industrial Index Monthly & $2004 / 06-2014 / 02$ & Slow & $\mathrm{SA}$ & $\Delta l n$ \\
\hline 135. & Nanhua Agricultural Index Monthly & $2004 / 06-2014 / 02$ & Slow & SA & $\Delta l n$ \\
\hline 136. & Nanhua Metal Index Monthly & 2004/06-2014/02 & Slow & SA & $\Delta l n$ \\
\hline
\end{tabular}


Employment

\begin{tabular}{|c|c|c|c|c|c|}
\hline 137. & No of Employee: Coal Mining \& Dressing & $1999 / 12-2012 / 12$ & Slow & SA & $\Delta l n$ \\
\hline 138. & No of Employee: Ferrous Metal Mining \& Dressing & $1999 / 12-2012 / 12$ & Slow & SA & $\Delta l n$ \\
\hline 139. & No of Employee: Food Manufacturing & $1999 / 12-2014 / 02$ & Slow & SA & $\Delta l n$ \\
\hline 140. & No of Employee: Wine, Beverage \& Refined Tea Manufacturing & $1999 / 12-2012 / 12$ & Slow & SA & $\Delta l n$ \\
\hline 141. & No of Employee: Textile & $1999 / 12-2014 / 02$ & Slow & SA & $\Delta l n$ \\
\hline 142. & No of Employee: Paper Making \& Paper Product & $1999 / 12-2014 / 02$ & Slow & SA & $\Delta l n$ \\
\hline 143. & No of Employee: Chemical Material \& Product & $1999 / 12-2014 / 02$ & Slow & SA & $\Delta l n$ \\
\hline 144. & No of Employee: Medical \& Pharmaceutical Product & $1999 / 12-2012 / 12$ & Slow & SA & $\Delta l n$ \\
\hline 145. & No of Employee: Electrical Machinery \& Equipment & $1999 / 12-2014 / 02$ & Slow & $\mathrm{SA}$ & $\Delta l n$ \\
\hline 146. & $\begin{array}{l}\text { No of Employee: Computer, Communication \& Other Electronic Equip- } \\
\text { ment }\end{array}$ & $1999 / 12-2014 / 02$ & Slow & SA & $\Delta l n$ \\
\hline
\end{tabular}

Real Estate

\begin{tabular}{|c|c|c|c|c|c|}
\hline 147. & Commodity Bldg Selling Price: YTD Average & $1999 / 12-2014 / 02$ & Fast & $\mathrm{SA}$ & $\Delta l n$ \\
\hline 148. & Commodity Bldg Selling Price: YTD Average: Residential & $1999 / 12-2014 / 02$ & Fast & $\mathrm{SA}$ & $\Delta l n$ \\
\hline 149. & Floor Space Started: Commodity Bldg & $2000 / 01-2014 / 02$ & Slow & $\mathrm{SA}$ & $\ln$ \\
\hline 150. & Real Estate Investment & $1999 / 12-2014 / 02$ & Slow & $\mathrm{SA}$ & $\ln$ \\
\hline 151. & Real Estate Inv: Source of Fund: Domestic Loans & $2000 / 01-2014 / 02$ & Slow & SA & $\ln$ \\
\hline 152. & Real Estate Inv: Source of Fund: Foreign Inv & $2000 / 01-2014 / 02$ & Slow & $\mathrm{SA}$ & $\ln$ \\
\hline 153. & Real Estate Inv: Source of Fund: Self Raised & $2000 / 01-2014 / 02$ & Slow & $\mathrm{SA}$ & $\ln$ \\
\hline 154. & Real Estate Inv: Source of Fund: Other & $2000 / 01-2014 / 02$ & Slow & $\mathrm{SA}$ & $\ln$ \\
\hline 155. & Building Sold & $2000 / 01-2014 / 02$ & Slow & $\mathrm{SA}$ & $\ln$ \\
\hline 156. & Building Sold: Residential & $2000 / 01-2014 / 02$ & Slow & SA & $\ln$ \\
\hline 157. & Building Sold: Residential: House in Advance & 2009/01-2014/02 & Slow & $\mathrm{SA}$ & $\ln$ \\
\hline 158. & Building Sold: Residential: Existing House & $2009 / 01-2014 / 02$ & Slow & SA & $\ln$ \\
\hline 159. & Building Sold: Commercial: House in Advance & $2009 / 01-2014 / 02$ & Slow & $\mathrm{SA}$ & $\ln$ \\
\hline 160. & Building Sold: Commercial: Existing House & $2009 / 01-2014 / 02$ & Slow & SA & $\ln$ \\
\hline 161. & Real Estate Climate Index & $2004 / 03-2014 / 02$ & Slow & SA & none \\
\hline
\end{tabular}




\section{C.2. Data Description: U.S. Variables}

The series for the shadow rate is from Wu and Xia (2016) and the series for U.S. policy uncertainty is the EPU index from Baker et al. (2015). Whenever the $\mathrm{Wu}$-Xia shadow rate is above $1 / 4$ percent, it is exactly equal to the effective federal funds rate by construction per $\mathrm{Wu}$ and Xia. All other series are taken from CEIC Global Database. Seasonality adjustment is performed using the U.S. Census Bureau's X-13 program: SA=seasonally adjusted, $\mathrm{NS}=$ no seasonal adjustment. The transformations are $\Delta$-first difference; ln-logarithm; $\Delta l n$-first difference of logarithm; none-no transformation.

\begin{tabular}{|c|c|c|c|c|}
\hline 162. & Effective Federal Runds Rate/Shadow Rate & $1999 / 12-2014 / 02$ & NS & none \\
\hline 163. & US Policy Uncertainty Index & $1999 / 12-2014 / 02$ & NS & none \\
\hline 164. & US Unemployment Rate & $1999 / 12-2014 / 02$ & $\mathrm{SA}$ & $\Delta l n$ \\
\hline 165. & US Consumer Price Index & $1999 / 12-2014 / 02$ & SA & $\Delta l n$ \\
\hline 166. & US Industrial Production Index & $1999 / 12-2014 / 02$ & $\mathrm{SA}$ & none \\
\hline
\end{tabular}




\section{Construction of the Wu-Xia Shadow Rate}

We use the $\mathrm{Wu}$-Xia shadow rate as the measure of U.S. monetary policy $(\mathrm{Wu}$ and Xia, 2016). Unlike the observed short-term interest rate, the $\mathrm{Wu}$-Xia shadow rate allows the policy to drop below zero. Whenever the $\mathrm{Wu}$-Xia shadow rate is above $1 / 4$ percent, it is exactly equal to the effective federal funds rate by construction.

Following Black (1995), the short-term interest rate is the maximum of the shadow rate $s_{t}$ and a lower bound $\underline{r}$ :

$$
r_{t}=\max \left(\underline{r}, s_{t}\right)
$$

If the shadow rate is greater than the lower bound, $s_{t}$ is the short rate.

Furthermore, we assume the shadow rate $s_{t}$ is an affine function of state variables $X_{t}$ :

$$
s_{t}=\delta_{0}+\delta_{1}^{\prime} X_{t}
$$

The state variables follow a $\operatorname{VAR}(1)$ process under the physical measure $(\mathbb{P})$ :

$$
X_{t+1}=\mu+\rho X_{t}+\Sigma \epsilon_{t+1}, \epsilon_{t+1} \sim N(0, I) .
$$

Then, the stochastic discount factor is

$$
M_{t+1}=\exp \left(-r_{t}-\frac{1}{2} \lambda_{t}^{\prime} \lambda_{t}-\lambda_{t}^{\prime} \epsilon_{t+1}\right) .
$$


The price of risk $\lambda_{t}$ is linear in the factors

$$
\lambda_{t}=\lambda_{0}+\lambda_{1} X_{t}
$$

It follows that the risk-neutral measure $(\mathbb{Q})$ dynamics for the factors are also $\operatorname{VAR}(1)$ :

$$
X_{t+1}=\mu^{\mathbb{Q}}+\rho^{\mathbb{Q}} X_{t}+\Sigma \epsilon_{t+1}^{\mathbb{Q}}, \epsilon_{t+1} \stackrel{\mathbb{Q}}{\sim} N(0, I) .
$$

The parameters under $\mathbb{P}$ and $\mathbb{Q}$ measures are related as follows:

$$
\begin{gathered}
\mu-\mu^{\mathbb{Q}}=\Sigma \lambda_{0}, \\
\rho-\rho^{\mathbb{Q}}=\Sigma \lambda_{1} .
\end{gathered}
$$

The shadow rate term structure model (SRTSM) is described by equations (4) - (8).

Define $f_{n, n+1, t}$ as the forward rate at time $t$ for a loan starting at $t+n$ and maturing at $t+n+1$. The forward rate in the SRTSM described before can be approximated as

$$
f_{n, n+1, t}^{S R T S M}=\underline{r}+\sigma_{n}^{\mathbb{Q}} g\left(\frac{a_{n}+b_{n}^{\prime} X_{t}-\underline{r}}{\sigma_{n}^{\mathbb{Q}}}\right),
$$

where $\left(\sigma_{n}^{\mathbb{Q}}\right)^{2} \equiv \operatorname{Var}_{t}^{\mathbb{Q}}\left(s_{t+n}\right)$. The function $g(z)=z \Phi(z)+\phi(z)$ consists of a normal cumulative distribution function $\Phi(\cdot)$ and a normal probability density function $\phi(\cdot)$. The exact expressions for $a_{n}, b_{n}$, and $\sigma_{n}^{\mathbb{Q}}$ in terms of deep parameters can be found in the appendix of Wu and Xia (2016). 
The measurement equation related the observed forward rate $f_{n, n+1, t}^{o}$ to the factors as follows:

$$
f_{n, n+1, t}^{o}=\underline{r}+\sigma_{n}^{\mathbb{Q}} g\left(\frac{a_{n}+b_{n}^{\prime} X_{t}-\underline{r}}{\sigma_{n}^{\mathbb{Q}}}\right)+\eta_{n t},
$$

where the measurement error $\eta_{n t}$ is i.i.d. normal, $\eta_{n t} \sim N(0, \omega)$.

The input data for the model are one-month forward rates beginning $n(n=1 / 4,1 / 2,1,2,5,7$, and 10) years hence. These forward rates are constructed with end-of-month Nelson-Siegel-Svensson yield curve parameters from the Gürkaynak, Sack and Wright (2007) dataset. The latent factors and the shadow rate are estimated with the extended Kalman filter.*

*The full details of the $\mathrm{Wu}$ and Xia model are described in their paper published in the Journal of Money, Credit and Banking (Wu and Xia, 2016). 